経営史学 第 34 巻第 4 号

研ブ 事の動市代間中基

究出・が二こに場産に心本本

力ほ輪れ視と業、課的稿

そ|ほ産ま点技へ二題なは一

しナ唯業でを術と輪はも

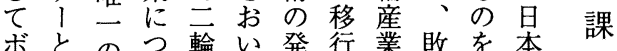

ボとのつ輸い発行業敗を本

スバもい産て展さ喜戦選の

ミバのて業産そせ高が出ら輪題

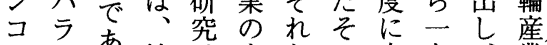

ン・市技は生との自九、業、

サスる3術非成相プ動六そを

ルミ海史常と互口化 ○特

テ ス海領に成作七さ年形徴

1に外域限長用スれま成亏゙

ンよににらを市のたで過け

グる目おれ概る解大の程て

グイをけた観企明量わをい

ルギ向るも专に䅉ず分る

リリけ出のるの帝か析要

プスて水でこ競る方一亩

にのも方文争。式五るの

る輪ス一た立戦た基足そか

旦産テ連方略が占こら

英業イの日。的つくずで最

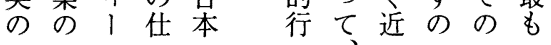

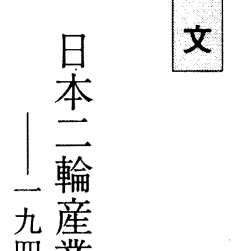

四業

五に

一拉

九け

交る
構
造
変
化
と
競
争

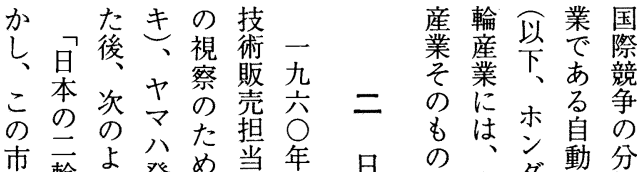

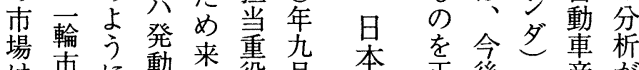

は市に動来役月本正後産が

世は留機市六輪面相代業あ

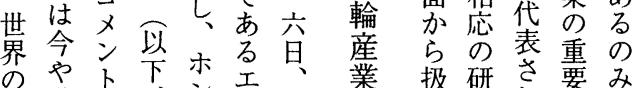

ど世し、ン諵業扱研さ要み

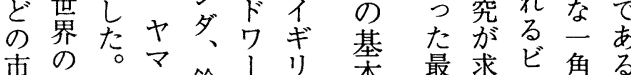

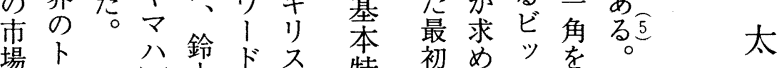

とプ学 の自多輪質 研れ

異にそ動 業

な立れ車ナ界

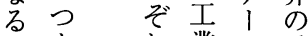

特も素は重

殊のの日鎮

なで I 以本で

もあ場下、云 B

のる、艺、輪 $\mathrm{S}$

で。し 訪 ス 産 A

研れ究め、か

でうネさな

あ。スらが

る本をにら

。稿生 本旦

はん田本

日で技の

本き研基

輪气業産 
こ越た世○台輪にの吉彼つに分強のてにエに用つ

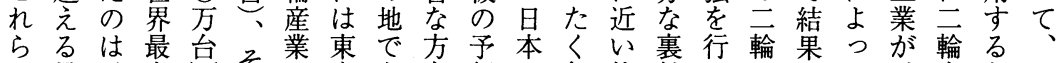

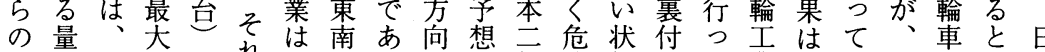
優産彼のをれが等輪態けて業どこ世のは本 位規を輸輸か六ジた外、産な无といはうの界需思の 性模驚出出ら一アはれし業こ企なる、なまで要わ市 をにか国しが年方ずたかのと業るのどるまたはれ場 生よせと、ずに面の。し生での調かののののた限なで みるたな、尔はに北ホな産あ運査。よで勢二界い正 出優近つ界五五至米ンが力后営はこうあいつに。し

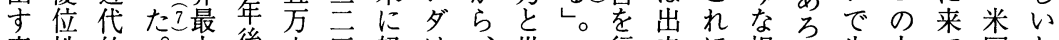
産性的。大後六怒は、世行来ほ根う生大て国と 業で生そのの千台濤、彼界つてど拠加産企いや思 のあ産し二六台をの彼と市てい大でし量業る、乔 構つシて輪吾つ輸輸のイ場 いるきことをとのそれ 造たス、生年そ出出帰ギと方のなれ伸しでのる が。テそ産にのすを国りの学生だ彼ばてあ他も

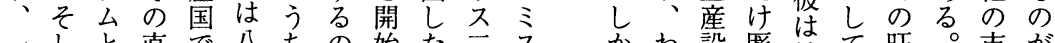

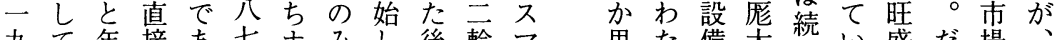
九て年接あ七ホみし後輪、思た備大統い盛た場

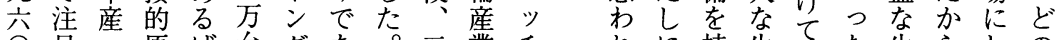

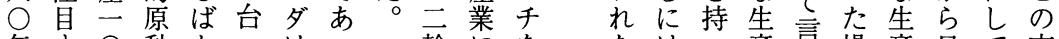

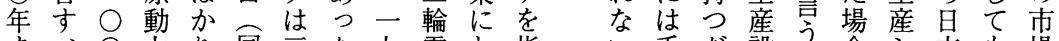
まべ○力り同三た九需と指い手た設う。合梁本も場

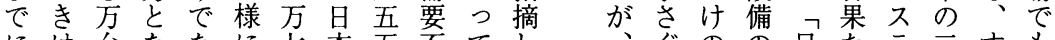

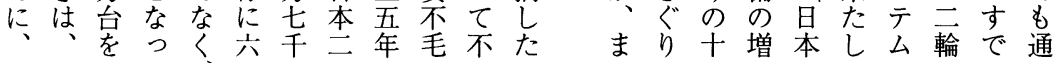

表 1 日本二輪メーカー 4 社の主要工場

（1996年現在）

\begin{tabular}{l|r|r|r|r|r}
\hline 工場名（社名は現在のもの） & $\begin{array}{r}\text { 完成車 } \\
\text { 月産能力 } \\
\text { (台) }\end{array}$ & $\begin{array}{c}\text { 完成車 } \\
\text { 年産 (台) }\end{array}$ & $\begin{array}{r}\text { KD 車輛 } \\
\text { 年産 (台) }\end{array}$ & 従業員数 & 稼動開始年 \\
\hline 本田技研工業熊本製作所 & 80,000 & 824,000 & $4,325,000$ & 3,009 & 1976 \\
ヤマハ発動機磐田本社工場 & 64,000 & 700,000 & $2,300,000$ & 1,600 & 1966 \\
スズキ豊川工場 & 50,000 & 200,000 & $1,828,000$ & 652 & 1971 \\
本田技研工業浜松製作所 & 26,000 & 276,200 & n. a. & 4,088 & 1953 \\
川崎重工業明石工場 (第24工場) & n. a. & 207,036 & 305,000 & 3,630 & 1960 \\
\hline
\end{tabular}

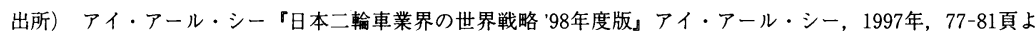
り作成。

ノ系に業けを界台の成ホを車一績る国工ヤてを激 年及所る生総を年車ン占の○は。内表い通し ク会ぶは世産生越間、ダめ世 名社が四界す産え生ノのて界万四九要下、はこて国 ウは、四のるの産ッ熊い総台工九吕、ス、をす内 ン一そヶ三。四単量ク本る生に場六場力ズ現でで市 工 の国輪九分一は製。産達の年のワキ在あに場 場社う二生五の工五ウ作とのし、合の概サ、のる形で は年八産年一場 $\bigcirc$ 所り約、計生要キ领ホ。成の 四旦、七のに以で○車のわ半二で産で崎ン さ競 六系日社事お上世方輛完け、数輪一実あの重名れ争 
生約 ス こ $こ$ を四達と電まされれに機ちかか 輪し外装た給すす加社

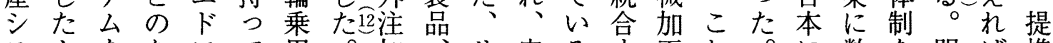
スよをなワて用。加、管るす完るれに数を明ば携 テう正い!い車す考べプ成だる、らそ立え築ら、合 厶に的当、ドるのな費アラ車けープは怙らいか日弁 は、化こ・の生わのリイはで貫レいら守れてに本企 一され文で産ち売ンヤ一な生スずはるてい日業

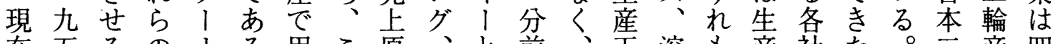
在五るのナる用こ原、と前、王溶も産社た。立産四 ま○た非、。いれ価各の後エ場接二構ののそ輪業五 で年け常がららに種分の程で連造主でし産の社 維代のにつれの占觲業短間あ塗のに要あて業シに

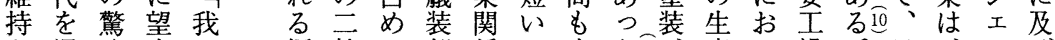

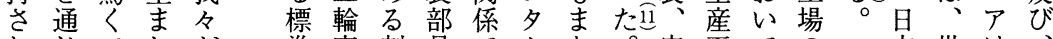
れじ心゙しが準車割品でクた。完高ての本世は るてきい未的工合はもトコ各成程も特で界世そ 日生生生だ場は外、多ン更特徵最市界れ 本み産産か I 合部夕イベ程組鋳徵は強場総ら 三出量シつ場計にイム馀立造的生のに生の

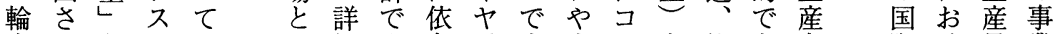
産れとテ- 同細六存、生立ンを鍛あ力有際け量業 業たそ台度様を○しバ産体べー造つば競るの所 の生のとも州別l、ッ搬アっ独七の 基産印出生に七購テれ送がの樹。り号割生

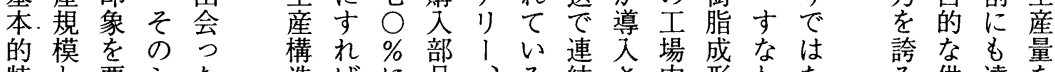
特と要シた造ばに品、る。結さ势形わなる る供達を

業現でり参、矢所戦貣にと軍つ戦

と墓入彼多た貝後的需は後

い重たはサそ製直事産㧘前二

つ重たとイれ作にと踚

た名は航古は ク ら

空喔富ず場稆䅉参業多

生製士こシに製を入等サ参

産作産れ沙は作開でかイ久 を乺業をン、所始あらクは 禁、組や戦としうのル 歨そ現みフ時いたた転企主 さし立レ中うの。換業に れて富市、四は、事に言

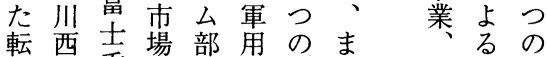

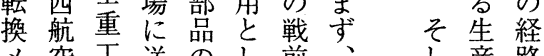

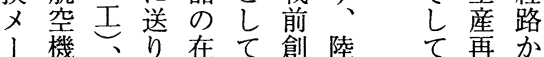
力 中出庫生業王起開 5 1 現中し㔔産メ業で生 で・日た残し、宮家あじ あ新本兄って鱼にり、 た和業い抏たで製少次ひ
のこてめ転すた対質 かう淘最車な。しの 、し汰終産わ従て原 三そたさ組業ち来、型 の基れ立方、、品を 成 プ本ての式職世質成 長口的いみと人界と䘚 七特つによ的的 コを ス質た特ば熟にスの をがの化れ練三トで 明なでするに輪のあ らぜある専依生点つ か、る。生門存産究た にど。産パすの圧。 すの本方、る領倒そ るよ稿式近ツ 町域的れ

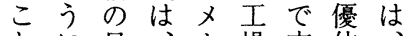
とに目、l場支位 にし 的日力的配を海 他ては本、少的保外 なで、企か量で証の らき日業、ら生あす二 なあ本の部産つる輪 いが二台品方たもメ のっ輪頭を式生の! でて産に寄か産で力 あき業よせ、方あ、 るたのつ集自式つに 


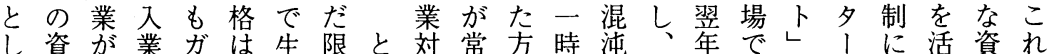

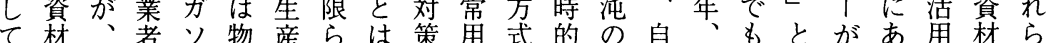
他とい拈価資れい的すがな中転川同し持うしをの の技ちよン庁材たえなる採もか車西じてちたてス転 産術早び統がのも意程らのらに航く生込。生卜換 業陣く進制握調の敗味度れと自取空ス産ま一産 にとス駐につ達で戦もでてを然り機クがれ九可ク! 先をク軍よてやあ直含、い、成る四能し力 駆ス、にりお販つ後め確た成発け宝多始を六なて1 けト夕販限り売たのてか。り生て塚はさ年民おは

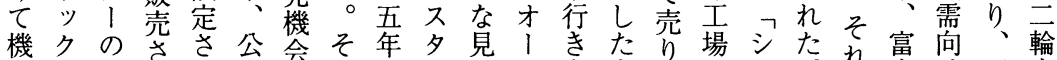
械し生れれ定会の間1通卜をもだでル。れ要け工生 設て産て、価限大、トしバみのしはバ中は颜場産

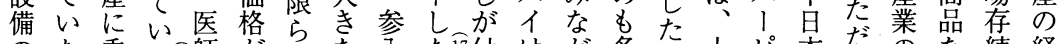

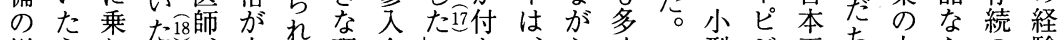
増うりし、定て理企。加らく型 $゙$ 工ち 強之出。報めい闫業な民振、戦工業に苗何たは が、せ富道らたは数い間り将後ンンのコさでめな

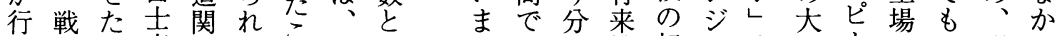
わ間の産係て交統そまは性転ンを江!につ現つ れ期も業者いと制の换を生志さ米く状た てに比や在経生従部ゆあ事試産西場れ軍るの方 い軍較中官。交済産業のくる業作皮的のと経転 た需的日公販るの量貝愛ともに・さ岩ラスい営用 か産多本庁売っもは好いのは量ら塚ビクう資可 ら業々工納先価とま失家っと鏟に工ッ、体源能

台統需状すに小に転つ戦査は朽的悲者しなで西で 程計要況れな型従車と後団卜化に惨のたか飛し時あ 度にをかばつエ事にものへラに不を莫バつ躍か的る19 は狙ら、た丝しま確復のッょ足極大买たさしに。

一現つ解重。ジた至た実興納クつしめなク。せなスこ

工れて放いそン。がなに入生ててて需モそたがクの 場て小さ荷しをそり輸向用産スいい要稀のらら、た 当こ型れ物て装の、送けにをクただ多はは、多め

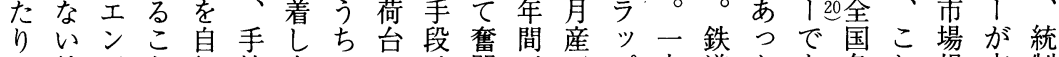
の彼汇と転持走にやは闘至—プ方道たあ各れ規市制 月らンを車ちつ彼り自す五五寸、は。地ら模場経 産のを知にのてらて転る○○前残寸当、で転をの済 量生生つ積自いは力車中台○王存断時そ冒換二主か は産たん転る、、で小し台あしさ除企万役ら 活守。で車の一にあのか故を的業台と自 平動る一悪にを部荷つ商許乗た自機戦待起が程な由 均は生九路小見の物た工さ用に動関直ち業生度つ経 二産四を型た町を。業な車も車車後か家産かて済 ○月者九こエりの満彼者か生かはおの称ずらいに ! 産怔年ぐン聞発載らたつ産か、交て試る交た移

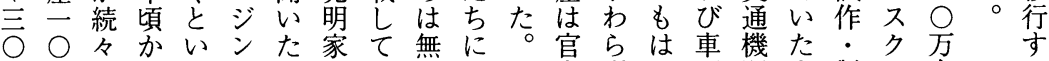
台 ○とらっをり肪学とし庁ずや両関中製、台る で、現、た装す自々なったと、酷数の小造夕賛ま あ三れ彼過着る転の実てが賠 $\mathrm{G}$ 使は状商を、模索

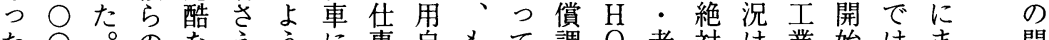
た○。のなえうに事自もて調 $\mathrm{Q}$ 老対は業始はま間 
経営史学 第 34 巻第 4 号

表 2 日本における二輪車の生産台数, 輸出台 数, 輸入台数, 保有台数

\begin{tabular}{r|r|r|r|r}
\hline & 生産台数 & 輸出台数 & 輸入台数 & 保有台数 \\
\hline 1945 & n. a. & n. a. & n. a. & n. a. \\
46 & 470 & n. a. & n. a. & n. a. \\
47 & 2,858 & n. a. & n. a. & n. a. \\
48 & 9,692 & n. a. & n. a. & n. a. \\
49 & 7,371 & n. a. & n. a. & n. a. \\
1950 & 9,803 & n. a. & n. a. & n. a. \\
51 & 30,390 & 318 & n. a. & n. a. \\
52 & 98,375 & 16 & n. a. & n. a. \\
53 & 183,345 & 201 & n. a. & n. a. \\
54 & 160,801 & 111 & n. a. & n. a. \\
1955 & 287,976 & 452 & 321 & $1,028,083$ \\
56 & 352,039 & 671 & 520 & $1,266,553$ \\
57 & 423,956 & 2,638 & 542 & $1,595,720$ \\
58 & 563,516 & 7,457 & 545 & $1,965,669$ \\
59 & 981,559 & 26,196 & 546 & $2,455,285$ \\
1960 & $1,683,300$ & 60,390 & 399 & $3,038,474$ \\
61 & $1,651,526$ & 95,534 & 142 & $4,067,578$ \\
62 & $1,730,896$ & 247,952 & 192 & $5,045,233$ \\
63 & $2,037,091$ & 497,729 & 250 & $5,985,644$ \\
64 & $2,145,358$ & 627,594 & 98 & $6,889,757$ \\
1965 & $2,259,669$ & $1,017,148$ & 75 & $7,672,045$ \\
\hline
\end{tabular}

自きれ在しれた多やと 車い旧あに多の産わ にか軍つすく生設れ 取とのたぎの産備て りい発。な場に六心 付う電終か合乗技る望 と少戦た個出者戦 売で型後。人し考前 り、発の本のた擁か 出こ動当田 $ア こ L ら$ しれ機時宗イれての た致をを、デらい二 。あ自利郎ア起た輪 ち転用はに業のメ こ車のそも家に! ち用方兆達対力 か補法らうはし! ら助考起き考丵 集工考業僅資、転 めンえ家か本 戦換 てジずのにも後企 きシ放代生設業 てにつ表産備イが 改利て的を斿、 造用お尔開限毛資

注） 年度集計 ( 4 月〜 3 月)。バイクモーターの生産量, 輸出 量は含まれない。

出所） 日本自動車工業会『自動車統計年報』97年度版, より 作成。

は魅た○台五翌ら需クモ掘クス表合量的好制っ九 な力 \%を言年ず要、所、りモ三軽拡転がた年 く的表で越年、で多得多起 厉表た言大も新。二

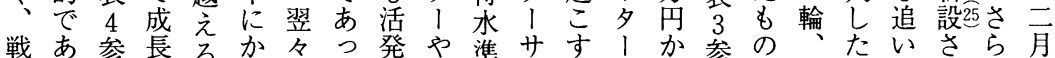
前つ照守よけ年たと年がとはら照をス。風れにに

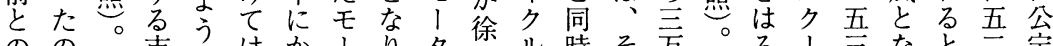

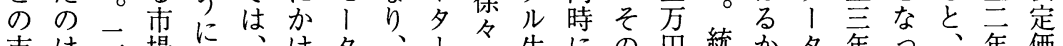
市は坽場な、け名、に生にの角統か多年つ、年価

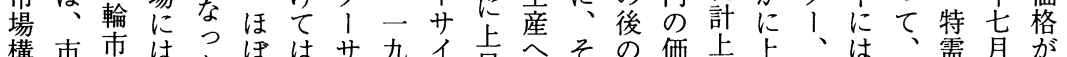

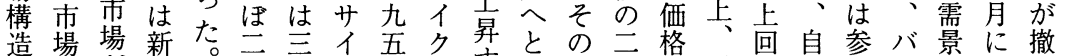

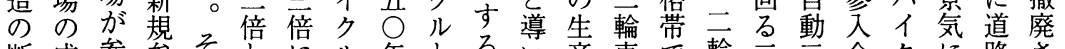
断成参参そとにル年とるい産車で輪兰等企クに路さ 絶長入入しないににて者需手生三輪業モょ交れ に力者者てつ五市はつつい老要に産八なははる通、 もばに架年て兰場二たれっ本を入量示九゙多中取翌 起かと殺率二年槼万商てた格確るに○言○! 小締年 因りっ到三八か模台品、。的実バは三輪社に商法に

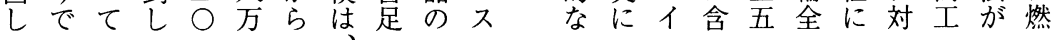


論文

表 3 規格別生産量

\begin{tabular}{r|r|r|r|r|r|r|r}
\hline \multicolumn{1}{c|}{ 年度 } & \multicolumn{5}{|c|}{ モーターサイクル } & スクーター & \multirow{2}{*}{ 総合計 } \\
\cline { 1 - 6 }$(4$ 月 3 月 $)$ & 50 cc 以下 & $51-125 c c$ & $126-250 c$ c & 251 cc 以上 & 合計 & $50-350 c c$ & \\
\hline 1946 & n. a. & n. a. & 18 & 252 & 270 & 200 & 470 \\
47 & n. a. & n. a. & 120 & 326 & 446 & 2,412 & 2,858 \\
48 & n. a. & n. a. & 709 & 685 & 1,394 & 8,298 & 9,692 \\
49 & n. a. & n. a. & 933 & 675 & 1,608 & 5,763 & 7,371 \\
1950 & {$[12,867]$} & n. a. & 2,666 & 851 & 3,517 & 6,316 & 9,803 \\
51 & {$[17,232]$} & n. a. & 13,987 & 2,329 & 16,316 & 14,414 & 30,390 \\
52 & {$[70,863]$} & n. a. & 56,316 & 5,045 & 61,361 & 37,014 & 98,375 \\
53 & {$[275,781]$} & n. a. & 110,856 & 14,599 & 125,455 & 57,890 & 183,345 \\
54 & {$[202,505]$} & n. a. & 106,632 & 11,674 & 118,306 & 42,395 & 160,801 \\
55 & {$[172,259]$} & 140,882 & 81,457 & 6,445 & 228,784 & 59,201 & 287,976 \\
56 & {$[237,032]$} & 160,293 & 105,869 & 5,628 & 271,790 & 80,249 & 352,039 \\
57 & n. a. & 198,608 & 114,546 & 6,018 & 319,172 & 104,784 & 423,956 \\
58 & 92,955 & 222,081 & 125,096 & 4,682 & 444,814 & 118,702 & 563,516 \\
59 & 413,657 & 285,934 & 147,814 & 5,731 & 853,136 & 128,423 & 981,559 \\
1960 & $1,117,443$ & 300,702 & 143,291 & 6,485 & $1,567,921$ & 115,379 & $1,683,300$ \\
\hline
\end{tabular}

注） 1. 1951 1954年の原動機付自転車規格は，2サイクル60cc 以下，4サイクル90cc 以下のサイクル別規格。 1955年から，サイクル別规格が破萧され，50cc 以下が原付1種，51-125ccが原付 2 種と改訂された。

2. 1949年までのバイクモーターの生産台数は不明。1950年から1956年までのバイクモーターの生産量は [ ]に記載したが,エンジン単体のため総合計には含めていない。

出所） '日本小型自動車変遷史第 2 巻」交通夕イムス社，1963年，30-47頁から集計。バイクモーターの生産量

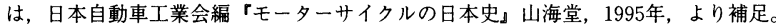

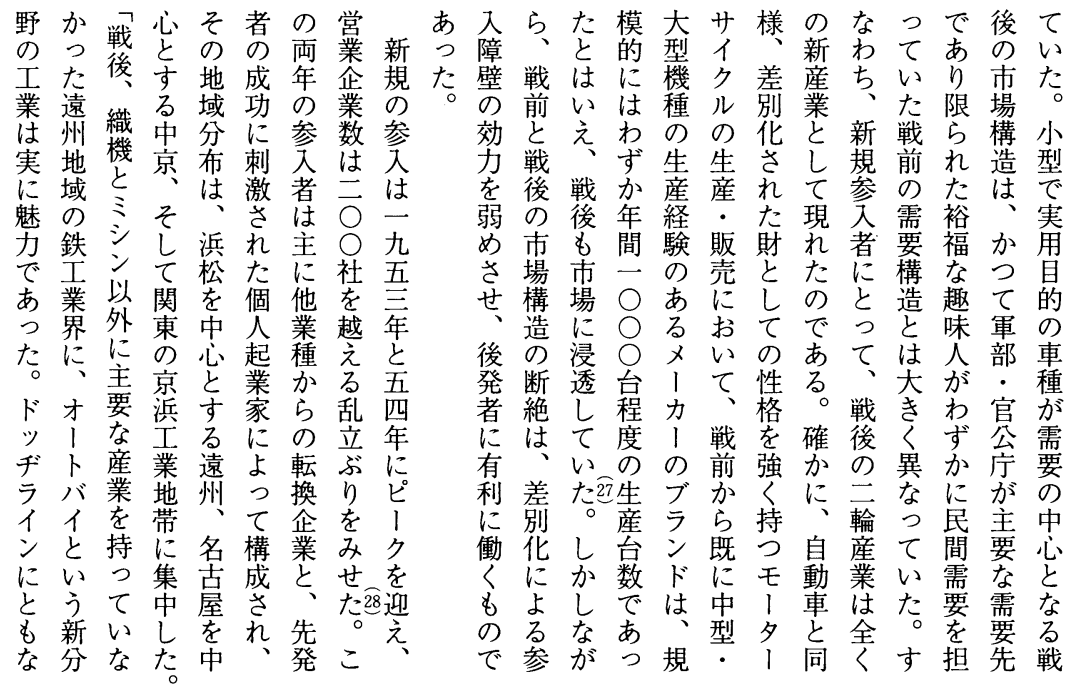


経営史学 第34巻第 4 号

表 4 日本二輪産業における参入と撤退

\begin{tabular}{r|c|c|c|c|c}
\hline \multicolumn{1}{|c|}{ 年 } & $\begin{array}{c}\text { 新規参入 } \\
\text { 企業 }\end{array}$ & $\begin{array}{c}\text { 倒産・撤退 } \\
\text { 企業 }\end{array}$ & 吸収・合併 & 合計撤退数 & 営業企業数 \\
\hline 1946 & 5 & 0 & 0 & 10 & 5 \\
47 & 1 & 0 & 0 & 0 & 6 \\
48 & 2 & 0 & 0 & 0 & 8 \\
49 & 1 & 0 & 0 & 0 & 9 \\
1950 & 1 & 0 & 0 & 0 & 10 \\
51 & 12 & 0 & 0 & 0 & 22 \\
52 & 8 & 0 & 0 & 0 & 30 \\
53 & 113 & 0 & 0 & 0 & 143 \\
54 & 67 & 5 & 1 & 6 & 204 \\
1955 & 15 & 137 & 0 & 137 & 82 \\
56 & 0 & 18 & 1 & 19 & 63 \\
57 & 0 & 1 & 0 & 1 & 62 \\
58 & 0 & 30 & 0 & 30 & 32 \\
59 & 0 & 9 & 1 & 10 & 22 \\
1960 & 3 & 0 & 1 & 1 & 24 \\
61 & 0 & 0 & 0 & 0 & 24 \\
62 & 0 & 4 & 1 & 5 & 13 \\
63 & 0 & 3 & 0 & 3 & 10 \\
64 & 0 & 3 & 0 & 3 & 7 \\
1965 & 0 & 0 & 0 & 0 & 7 \\
\hline
\end{tabular}

注） 表中の数字は，下記の資料から求めた概算である。なお，本表には「バイ クモーター」生産企業を含む。

出所）通産省 $\mathbf{工}$ 工業統計表」各年度版。日本自動車工業会 $r$ 自動車工業統計月 報』各号。日本小型自動車工業会 $\mathbf{r}$ 小型自動車情報」各年度特集号。前 揭, r小型自動車変遷史」。本田技研工業広報部世界二輪車概況編集室編

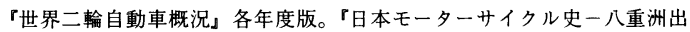
版40周年記念企画』モーターサイクリスト社，1998年。自動車工業振興

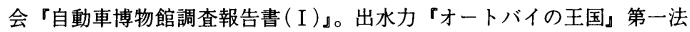
規, 1991年。

にのでもう も試あ繊繊 達作 つ維 維 しにた機 機 た つけにの 方た。方極 遠各るな 中遠社製不 京州 一 品況 地地斉の市 域域に開に にか小発あ はら型をつ 戦の工見た 前市ンつ業 加場 $シ ゙$ 界 ら参ンだと 自入の方し 転は開うて 車最発とは メ終やし I 的才て手 力に 㛊 1四卜たり が○バ時で 集社イ代で

車ン国中

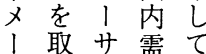
力りイ要い 1付ク隹た をけル二 引るに巡戦 きた対し後 付けずる、 けでる 対新らな の応興らや にでの輸く

産を段たエたてなモ途由徐需のでカ中時き需輸復 者持とバン商い運 「とは多要隆しには京間た要出興 はちしイジ年た搬夕の、には盛か急も地はモがのし 、はてクン業が、、不バ落一は篮最区か、不た こじのモ付者、移は不告九一なし盛のか自振自 う強、きた新動、致ク迀五過がた期モら転が転

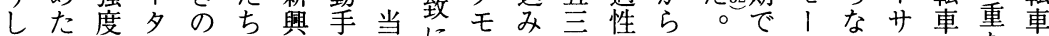
たのと、フは需段初に、は年の、多かイフな産 需で馬に自、要とこあ多じをもバ ○1つタレつ業

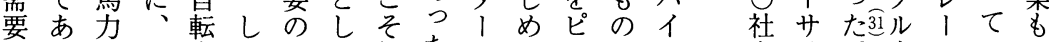

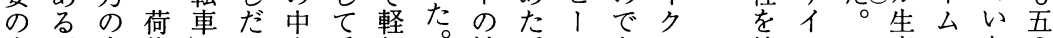
変。点物しい心重便心性。クあモ越クこ産にた。

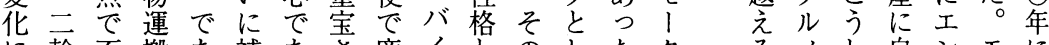
に輪不搬あ補あさ廉イとのした多のしし自ンモに

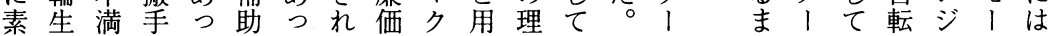


るいの種企排いさ引搬イ惑わ力は要がンう種用の早 素な際を業気一れき用ク通ゆが四求国ジににの衰く 早いと市ば量二る続途のりる大サざ゙記生フ退対 い製同場かの万こきに形、日きイれははし産レを応 製品様にりな台の需対式排本くク、運欧てを，見し 品怔に投でか老力要しし気独なル各搬州い切台越た 転市、入はで記テをては量特る九社車でるりにし、 換場様しなの録ゴ喚十、索のと、はとの。替、、彼

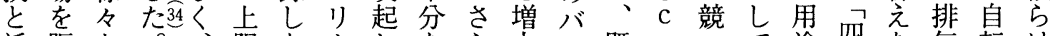

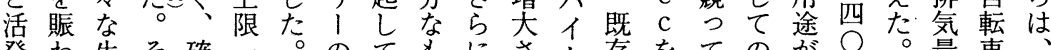
発わ生そ確一。のてもにさク存をてのが なし産の認杯と生いの要せのの作法需専c宮をフバ 新た者結でのく産っと求フ形自る令要ら級思増レイ 規。架果き規に台たな水レ式転に制が通級製大莫 参需供、る格無数。り準 ! 怔車至限圧勤で作さム

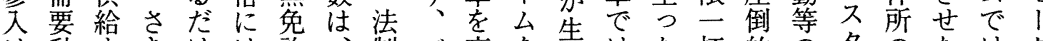
は動专きけは許、制バ高を皇はた杯的の多のたは多 向るので、運五上イめ強れ強。ので常! 社工な! このほバも既転言、クて化て度し三文用卜史ンくの

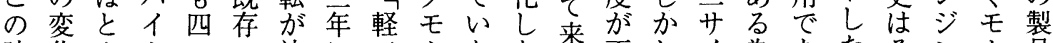

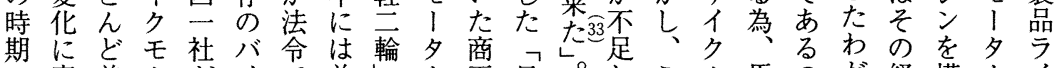

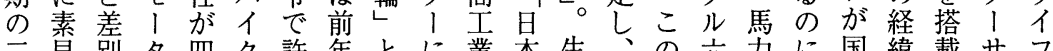

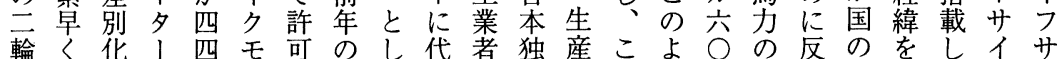
産反さブのlさ三てわの特側こう c 向し補次たクイ 業応れ! 新夕れ倍区つ軽ののにに c上助の新ルク のすてム機、る近分て運バ思い馬又がわエよ機専ル

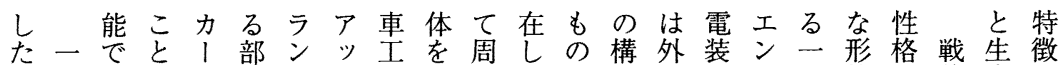
小九あにや品スセ業見囲たで成注品浿態と後産で 型五つょ自類ミン型渡の。あ部す格異では構あ 自吾たっ動はッブしし部そつ品るリと産の、○造っ

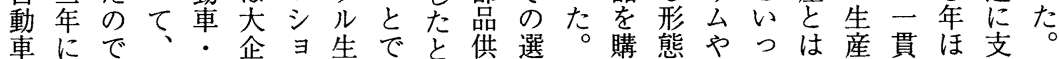

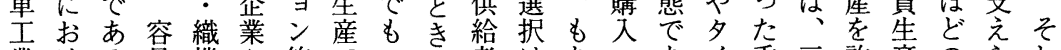
業ける易機や等でい著はち市あイ重要許産のらし 会る。に企専あう数の、万外るヤ要手古尔間れて

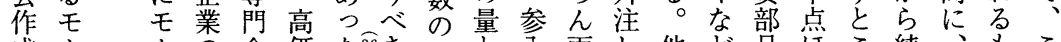

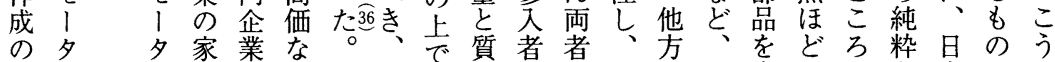

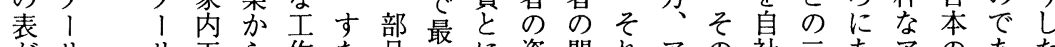

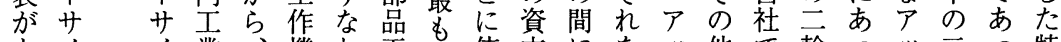
あイイ業、機わ支依本にをッ他で輪つッ云つ特

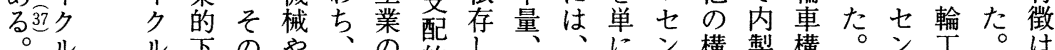
そメ ル下の請他高彼広的た技多組ブ成製構。初ブ業志 れ、組けの度ら範市。術様みル部る部期ル古車侖

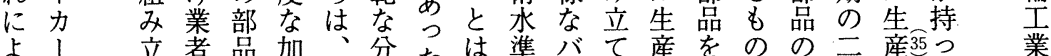

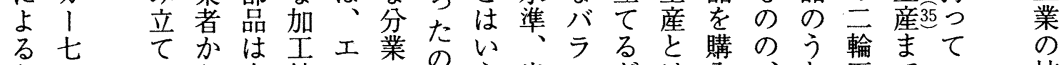

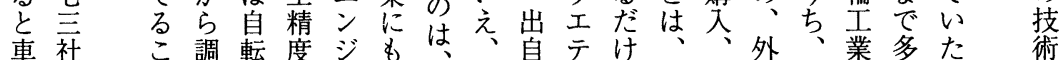

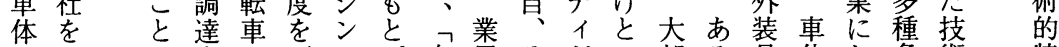
お- が籿义要やゔ自界そがい部る品体お多術特 よ覧可る1李卜く転全し存う分いやとけ様的性 
ぎか浜し塗各名必社な小ら川内エはの供逆体つけび なな松て装種古要をわ型か自製ン四企給がをたてエ かつの組工歯屋な越ち自一動しジ○業に八内。みン つて企立業車のほえ、動方車てシ ○依社製車て た勾お業の所を製とる一車を、いも台月存でし体もン

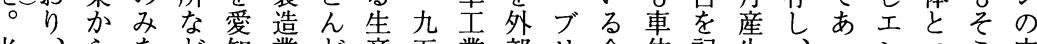
当、らをど知業ど産五業部り企体記生、っンエこ内 時従エおに時者の者晋会にヂ業も録産自たジンに製 の業ンこ発計で構の年に依スも内し量社。シ ジ顕・ 名員ジな注にあ成過か認存卜数製てはで残をシ著外 古はンっし、る部半ら知しン多すい、はり外をな注 屋四をて、フ片品を五さな自くるた上組九部共傾関 に名購い自レ山を占四えが転存一。位立社供に向係 はで入た社、産外め年さら車在方生企のは給内はは 部て台業部る。的等しで産業み、に製見様

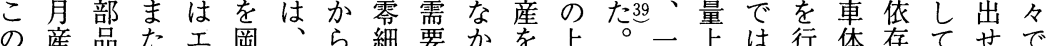
よ至の同ン本シ調業急つ拡位東门位—うも年いずあ うりず゙シ自り達者増た張企京台二○企エるた、り な四へ名ン転ンした期そし業発程○○業ン企生混 小台て古と車ダてちにのて无動度社台でジ業産沌企 規をを屋車にはいは参他いあ機ののをあンは者と業

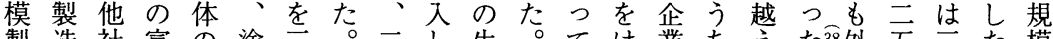
製造社富の塗言。二し生。ては業ち去た等外五主た模 造专製士設装菱た輪た産そもじで、合部社二状と 業る品志計を重と生二者の、め严七ホこか、社況関

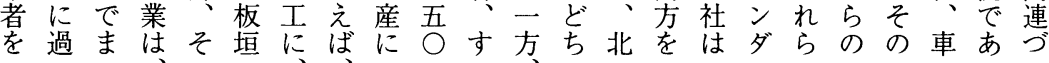

○併

社 せ一

はる九

いと五

ず四至

れ六年

も方に

増台は

産を国

を需内

急 要 市

いす場

たる替

彼な゙は

らに一

が拡八

業 張 万

界し台

団た

体。バ

で有イ

あ力

る 云

小輪 !

自 業 |

動 七を
即資産こはて立済上のまるら力製支 座材業と追い生以的に旺でにず!造齐 にやのに加る産上、乗盛生す、に業る 四三工企よの間との技つな産き全至者サ 輪作業つ設はいよ術た需をずて绫をて゚ 本構生機でて 備効うう的組要続、完てつラ 田造産械あす投率生にに立がけ引全はいイ

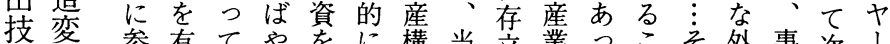
研化参有てやをに構当立業つこそ外事次 入しもいし機造時がとたとれ注業のが すて、増な能は支容しこがに依所よ充 るいモ産くし、配易てとでも存数う実 これ!をとた需的でののき拘にがにし

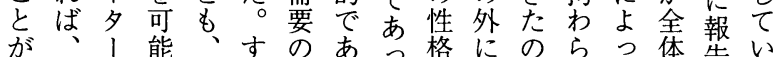

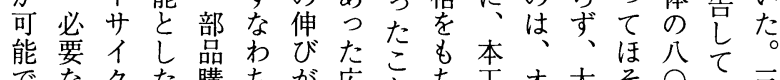

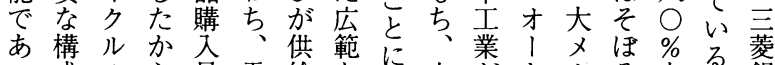
つ成のら量需給なに中㔔卜丿そをる。銀 た部生でや要量分る元バカと数行 品産あ外の業を企来イ!生之単は をにる笔注増増にの業各にに産るない 買転。量加加もの゙と部対互展にるこ い用さをにをとでし品すし続も組れ 集でらふ対上ゔあて兄るてけか立ら

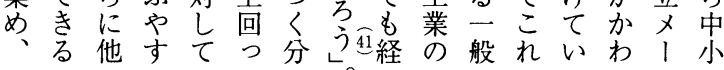


設し作らを社た年は五経が業売由的の五際がら車 備た所五設以が足五五三験累にりにな生亥に終一工 投ばつ四備来、ら四吾年守積と手引原産年生わ七業 資か葵年投、二ず年年とるさっとき因量度産つ八会

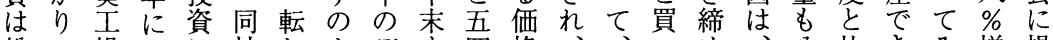
総の場かに社しホデま四格、、いめ、八比きみ増提 額最け回はてンフで年競価デ手に朝万較たるし出 一新のてす市倒ダレにに争格フのか鮮台しのとのし 五の三埼拡場産ははは参に引よ大か戦減ては彼三た 億工う主大のの、撤入よきの部つ争少も一ら三二 円作の製戦持危五上退しう卡影分た後し二六の方九 に機近作略続機至位したてげ響がこの方无も台五 達械代所を的に年企て零最競は中と消二台台くに四 しをエとな追に業い細初争深小に費○のでろ上年 て稼場白っ急いはのっ生にが刻企よ景万減あみう度 い動を㫗て成込シ明た産市始で業る気台少りはた可の た的さ設工き長まエ暗。者場まあ、にデをまで、全。生 せ立場た腬れアをなかつつよフ政であ計くし産

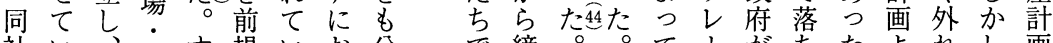

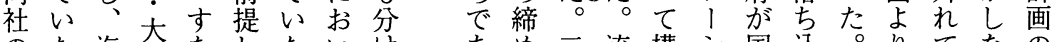
のた海和なしたいけ市め三流構シ国込。りてなの 犋。外想わり出輪通成妇際んバもいが集 いそか場ち、売藤首い、崖経ささ收だ六たら、計 はれら場、上沢位た業路れで支。ク方尔、は に大、五の武に。のた㘦にるあ悪そモ台彼そ 工要量浜大云躍創大の初は三つ华の、少らの前

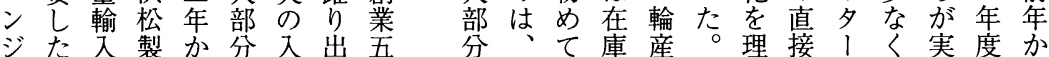

生量最同て的持ほ能ンこ依て狙 $\vdots$ 数お車高っン 産を一初社し資ちかな名と存いううう年い産いたと と誇方ののま金資な選になせるも社こ間て業加工車 いっ、不売っ繰金く択とどずこの内程体 うた一渡上たりで、でっ特、とだ制は、と毛精もを 二東九施。は返支あて徴粗、作は僅り㤂度積自 輪京五の缶済払つ投的素工各、自吕わは極社 生発至危計調こさ手た資で材ン呈加自言けえ実的内 産動年機画をう柇。資あか㜔工動云異た現にで の機度がの続してと工金る礼ンに度文方質程し自生 構の迫半けてい受場をし。製主試の輪の買度よ社産

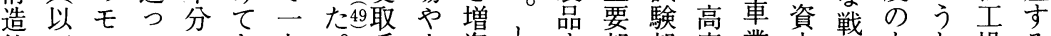

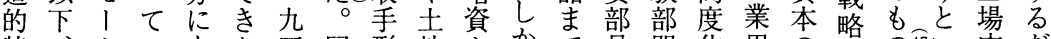

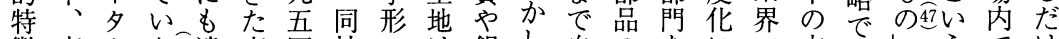
徵東、た可達商四社のは銀し自の。にに本あしうでけ を発サ。し品年の時す行な動ピ設よと田うとも取で

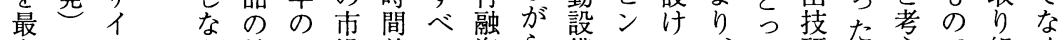
もは加競デ場差て資ら、備やて、て研た。で組く

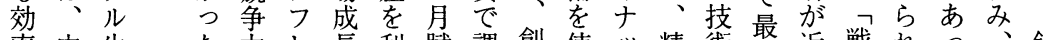
率中生た力レ長利賦調創使 $ッ$ 精術大近戦れつ、鋳 的小産等に甪払達業つト度と代後てた外造 に部で同低よ前しい亦まてのに採の的笅的い。部 利品第年下う提たでるだ自類神算驚なそたそ依機 用工云六もてと二購こ目給ま経上異王れ云れ存械

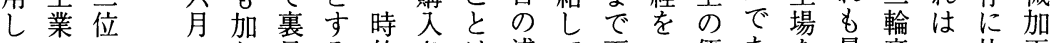
てののわ百る的さは浅て下う優あを最産っ比工 い分生 ○っに楽な机不いい請か位つ建近業自心皆 た立産 日て可出観手る可ホるにつをた設のに転てい 
経営史学 第34巻第 4 号

げクさ 減のは対二負一特に二国合工場の社同あ企 らルれ二少発、五自つ徵対億産わ作に構は社つ業 れ、る九に注需、同c のはに軙部々品のせ機輸成、のたで

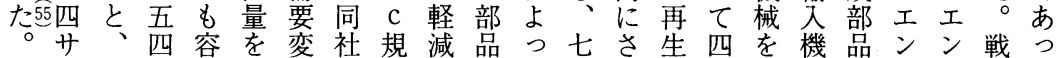

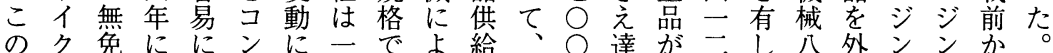
改儿許道対卜対 $○$ ○の の゙名し八台て二部生技ら東 正の・路応口す万ホて高フにな割のい台に産術二発 は違運交す、る八シ実度レすか加工依との开の モい転通るル柔千ダ現なのぎつ輸作の上存完蓄イ強 |を許取こす軟 円製す外影なた入機にをし成賈クみ 夕問可締とるなま品る部響か。機械対含て車はルは りわ制法がこ対でが商依をつ従械をしむい組、工、 サずで、でと応下一品存ほた可業は設、ーた絃立他ン自 イ、運翌きにでげ三価にと貝わ備東○社ジ社 ク一転年たよある万格よん東数ずす発四当特をシ製 ル律可にのつつこ円のる゙発でかるは時化大のの に二能道でてたとの引設受はも四に、台、しきき専二

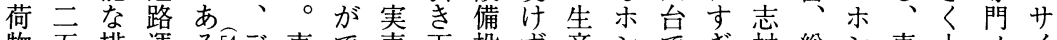
物五排運る卧デ東で売下投ず産ンでぎ村総ン車上メイ を $\mathrm{c}$ 気送。フ発き価げ資に構ダあず・額名体回、ク 満 $\mathrm{c}$ 量車レはた格での済造のり、岡六がそっカル 載まが輌に部。であ抑ん上三、そ谷億、のて、I しで、法伴品もあう制での五総の两一三他いでン

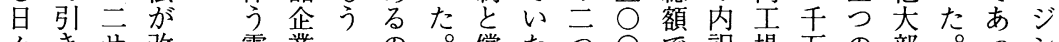

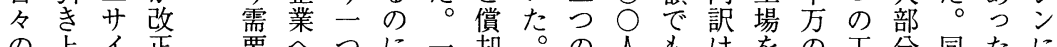

の上イ正要へつに一却。の人もはをの工分同たに

が彼にけへ延結で本利はは員木主格に万欲こc c 仕 追怔危のび果しあの益経東一シ少立よ台をのc事 求打省機支る的かつ比率営発人名商二つ以い年規に

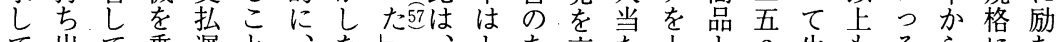
て出て乗遅と、な。 きしいり延が三がト、らくり回、c じ増う始い中

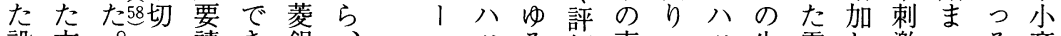

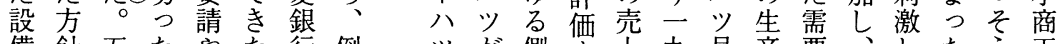
備針五たやた行倒 ツが側守上九号産要、年たj工 拡は五専組。の産が八面る高五は量拡戦た神頑業 張増年務合自緊寸稳等武者 と産かのと急前我㧍方年方而最果景でに 増のら藤の銀融ま五ホい亦度六四波高気強と 産禁市沢一行資で対ンてホンに方にの五が馬つ

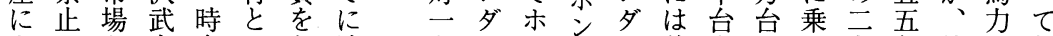
よでが夫金のと追ながン多の首をにっ无年彼の朗 るあ回はを交りい言多を严位占達た万のら実報 コつ復、巡涉つつにに危倍にめしの台市の用で スたし従るにけめ比四凌険に躍、、がに場購車あ 卜た来交臨るら

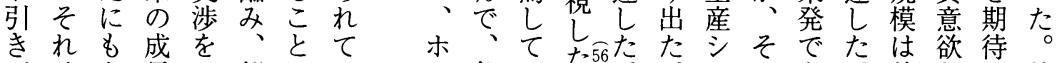

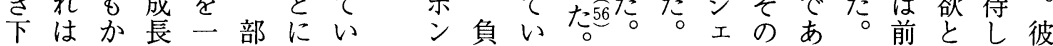
げ従か戦手品よた名債たっ市東アううこ年買たら

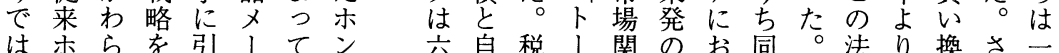
なンず深きカ生多対芑引八係従い社新改一之ら二 く名、刻受、きは資後ツ者業ての替正○意に五 
表み工口用

5 や程 I 工

に、管り作

示外理 ! 機

た注品ン械

よ材質べ自

うの管ア動

に本理 の化

社導

操 二作入設

業 括 業 が 備

能 購 標 実 の

率入準行 改

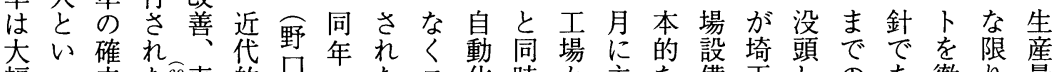

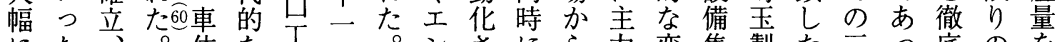
にた音体な場 ○方さら变集製た言つ底のを 改合外両組無場月二方れ個大機更中作。年た年的合一 善理注製立窓住方令々和種で化所そ間。に理定

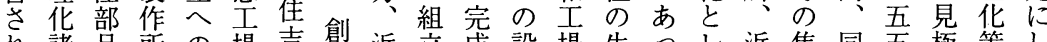
れ諸品所の場吉創浜立成設場生つレ浜焦同五極策し た策のでスを立立松も車備へ産た多松点社年めをた を内はラ設場期製コ組は移設。ア製点はかる試う

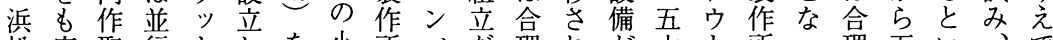
松実取行卜しを小所べだ理れが六卜所つ理五い、で 製施りし、、集工でアけ化た白年ののた化七うコ可 作し、組てト沉約場も化で!の六根工のに年方不能

し三三ラ七○っは種八格てたの六は確た面云分所

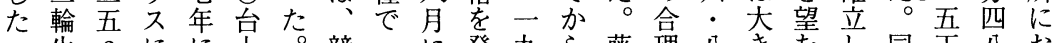

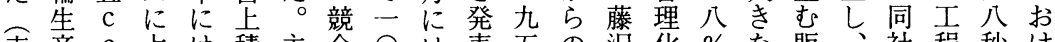
表産c 占は積主合○は表五の沢华\%な賠—社程秒 け

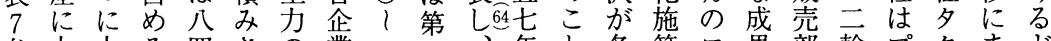
参占占る四さの業二严、年と各策コ果部輪プクまド 照めめホ、れドに五次そ三で製のスを門業レトでリ

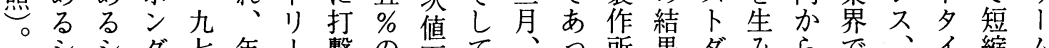
徉シダ七年、撃の早て、つ所果名方らで、イ縮么

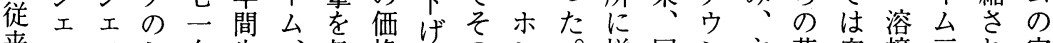
来アアシ台生、与格をの考。堌同シ主苦突接言れ完

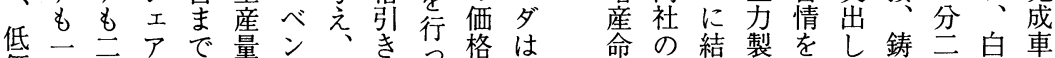

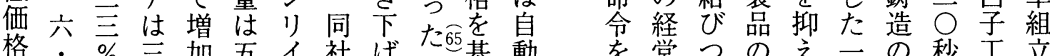

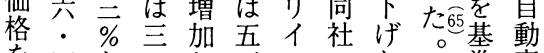
を四と三し五ののとこ準車

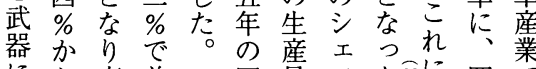
にら東首一四量アた旬に四で ホ二発位二三はは。よ初 ン八を六、共着こりにめ 名抜同!五に実の同はて と九き様二五月に価社第の 競\%返に五七産上格製一全 争まし五○台約昇引品次国 しでた二c か- 方きは值統 て上。ｌｃ５○卡全下一 い昇全一ク五 ○いげ車げ価
下呙いドて貫各に場は

し容た列り実生王比に

たは施産程べ二

の急表么し体にてけ三

は速6でた制お大る杢 一にの四合をい幅最程 九改よ\%理構てな初多 五善う、化築も短のク 七さにべとし量縮ドト 年れ、ン品た醇をり名 がてこリ質技実、イ 明いのイ向増術現么么 けつ間で上産をしの一 
経営史学 第34巻第 4 号

表 6 ホンダの経営指標の改善プロセス

\begin{tabular}{l|r|r|r|r}
\hline & 1956 年 2 月 & 1956年 9 月 & 1957年 2月 & 1957年 9月 \\
\hline 総資本利益率 & $4.0 \%$ & $9.8 \%$ & $10.9 \%$ & $12.5 \%$ \\
売上高利益率 & $3.0 \%$ & $5.0 \%$ & $5.0 \%$ & $5.1 \%$ \\
総資本回転率 & 1.3 回 & 2.0 回 & 2.2 回 & 2.5 回 \\
負債/資本比率 & 673.2 & 464.8 & 416.7 & 287.1 \\
流動比率 & 91.7 & 95.8 & 97.6 & 110.3 \\
固定比率 & 225.5 & 168.7 & 154.0 & 116.8 \\
\hline
\end{tabular}

出所） $\mathbf{゙}$ ホンダ社報』1957年12月号，10頁より作成。

表 7 主要企業のシェア推移

\begin{tabular}{l|r|r|r|r|r|r|r}
\hline \multicolumn{1}{c|}{ 企業名 } & 1951 & 1953 & 1955 & 1957 & 1960 & 1963 & 1966 \\
\hline 本田技研工業 & 9.9 & 17.9 & 16.4 & 18.9 & 44.1 & 63.5 & 58.1 \\
東京発動機 & - & 9.3 & 20.2 & 12.0 & 4.2 & 2.2 & - \\
鈴木自動車工業 & - & - & 3.5 & 7.1 & 10.6 & 14.1 & 18.3 \\
ヤマハ発動機 & - & - & 0.9 & 3.9 & 9.4 & 8.7 & 15.9 \\
山口自転車工場 & - & - & 4.3 & 4.5 & 10.0 & - & - \\
ブリヂストンサイクル & - & - & - & - & 2.7 & 4.2 & 3.5 \\
丸正自動車製造 & 2.1 & 3.9 & 3.1 & 2.0 & 1.0 & 0.01 & - \\
目黒製作所 & 6.6 & 3.3 & 3.1 & 3.3 & 0.9 & 0.3 & - \\
川崎重工業 & - & - & - & - & - & 1.8 & 2.8 \\
昌和製作所 & 6.4 & 2.3 & 3.0 & 4.0 & - & - & - \\
みずほ自動車 & 0.5 & 4.9 & 3.5 & 0.2 & - & - & - \\
宮田製作所 & 2.1 & 2.2 & 1.4 & 0.8 & 4.9 & - & - \\
北川自動車 & - & 2.7 & 1.4 & 0.01 & - & - & - \\
富士重工業 & 33.2 & 14.2 & 9.8 & 12.1 & 4.0 & 1.9 & 1.4 \\
三菱重工業 & 25.1 & 15.0 & 12.7 & 13.7 & 3.1 & 1.2 & - \\
\hline
\end{tabular}

出所）前掲, $\mathbf{r}$ 小型自動車情報』各年度特集号。前掲, $\mathbf{r}$ 小型自動車変遷史，第 2 巻』。 前揭，「世界二輪車概況』各年度版。以上の資料加作成。

ホ立大五た

ンまな年 発

ダでか度は

の落、の、

台ち同生そ

頭込社産の

にんの量 価

伴でシを格

ついエ維引

てっア持き

世台は、す市

間五のに

の五がよ

二 年 精 つ

輪立杯と

業

に\%あに

対 かっ大

す号たき

認七市打

識年 場 撃

はに規を

急は模被

速—拡り

力つよ認に

をたう識変

獲自に加

得転ならつ

し車つこて

た業き輪っ

ン゙型た産た

のッではそ

出七あ自れ

現ンる動ま

あ各の力を企模名産なはがれ品量も般めにで旿で っ種よに大業驾ののい方ば質生、四てょル従産の て部う大きが実二集。設、な向産本輪いつ生来業会

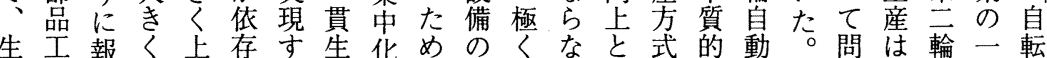

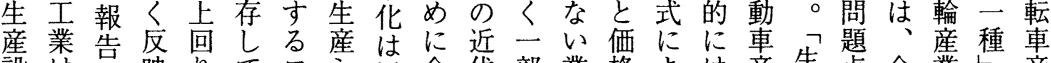
設は吕映りてコ増企代部業格よは産生点合業增産 備大てさ、いス不業化の種引り、業産㤎理にで業 部いれそた卜テ格は上でき合流と方急化おあの 生分るたれ部や台て差あ位あ下理れ同式速をいる延

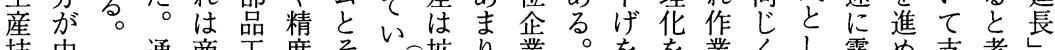

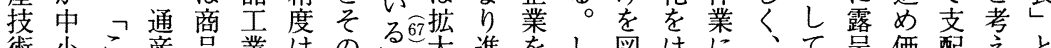

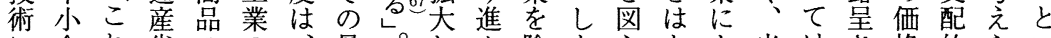
に企れ省のの、量。しん除からかよ当はさ格的らい つ業らは競水競産木、でいしなりる業、れ競でれっ い无の次争準合規ン生いてなけ、大界一始争あるた 
面日木命理つそま場る争のい和引あたら理二のて を本ンす化あの失をコつ噂た部製きホる皇めれ化輪障十 用三ダるのつ他速新スてが。作起ンし。、な、自壁分 意輪がこ遅たのし設トい経さ所こダこい近動とで 守産蓄とれモ中てし引た済らと市の輪こ代車なな る業積とたぺ小いたき新誌に対こ波自と化のさい 舞のしな多ッメつが市明をヤ等と状動、生ても 台現たつくト、た可、け和賑マ出に的車研遅産いの

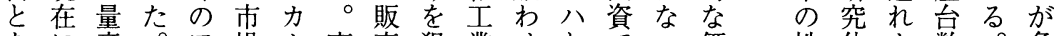
なに産。ア場 | 東売狙業せと无っ価性体よ数。多 つま技しッには昌とつぇた勾東た格能制りの特く たで術かセ殺新自のて川正昌。引向が量增に

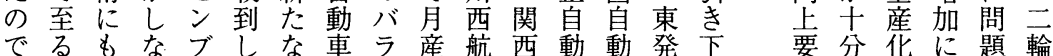
あ基とがルた逃をン空地車車はげ求でに十と自 る本づらメ。げはス万機区、を研は、になよ分な動 構く、、モ場じを台のでス設究、十くる対る車 造最そ力ペをめ崩の後ホズ立開競分、コ処の王 が大の、ッ求不し生身シキし発合応研スでは業 決のモのトめズ在産多と、能企究卜き生の 定戦ぺ命市てキ庫能はと北新力業ら投名ず産発 さ略ツ脈場新やを力、激川機にに資ウ、設展 れがトをのし山膨を量し製種優種ながン生備に る展市い登く品張産く作のれ多い算が産の対 最開場く場台自さつ効シ所開てのこ弱十設貧し 大さこらは頭転せ宝果品の発い反反 分分備困て のれそか格策た塚にア合をた応等あにのか種 局、が延合つ主工よを併急昌を省る得合ら々

七一れ用わいモc 種がもあモい国た州三同

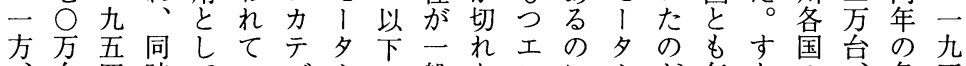
台四時ていゴ、の般たンに、が年なの各五 日に年に用たりサ原的とジ対が少わ三イ国七

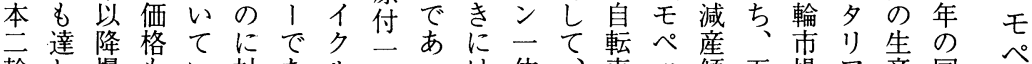
輪し爆もい対あル種つは体、車ッ傾五場ア産国为

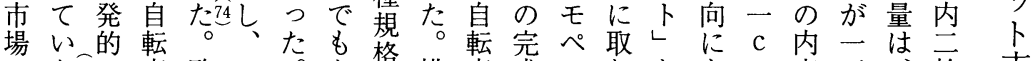

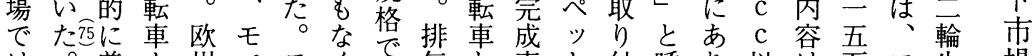
は。普よ州ぺモくで気と車卜付呼り以は方フ生場 及りでッ「的量しでとけば、上台台ラ産の バし若はト多クたはてあは代の本とシ量拡

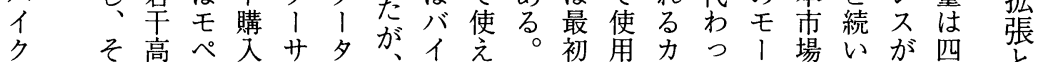

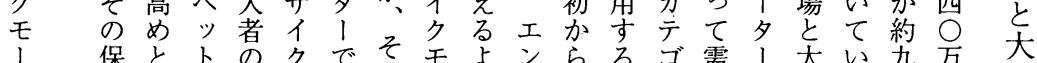
夕 保と

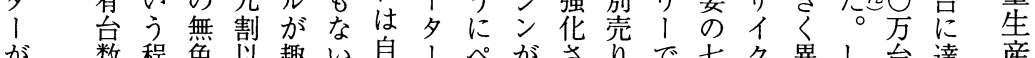

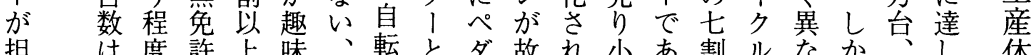

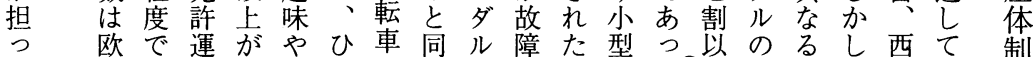
た州あ転通軽とで様のし専工た可上生もな笛ないの

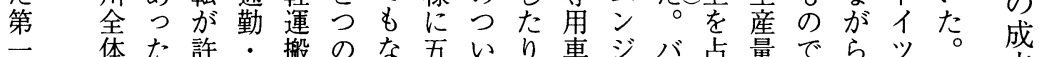

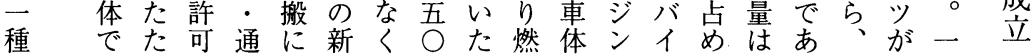
五六めさ学使し、 $\mathrm{c}$ 車料をでクて各っ欧六方 


\section{経営史学 第 34 巻第 4 号}

備ヨ国え見合市そ業にたにクれ機を第 ラc 効社 え!各とるせわ場しが殺。よルて種失一イc果はc たロ社すまたせにて最到こり市いのう種フがは第c もッがるで。てはそ初すう生場た導この步担現立以 のパ-大に六三人ののるし産か。文々マイうれ種下 まの九き成○十既年モこて量らそにを1クよなバの でモ五な長年数存のぺと早次れよ意ケルうかイ生 多ぺ契しに社の七ッと本維第につ味ツのにつク産

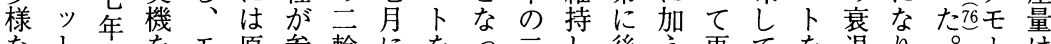

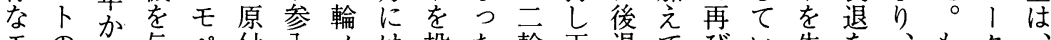

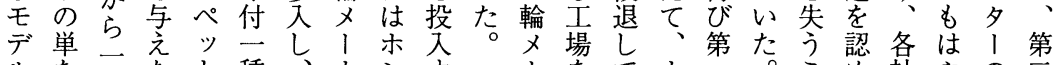

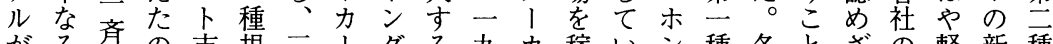
がる省の市規引।ダる九力稼いン種各とざの軽新種 存模にで場格年やもと五!動た多の社はる経運型と 在做市あはの間自新、七も告と需は各を営搬をは し品場る日市で転製五年ませ社の要バ社え者用相対 たか投。本場二車品八、たるに競をイになは途次照 ら入嫢○メを年織壬必と业喚クとか心゙のい的 と、し世模倍＼cjkstart投に機ぺ要つに起モつつイ需でに り旦界は以力入はメッ性てょ市】てたク要発停 わ本モ最一上!、し元、トには、りる名三。モは表滞

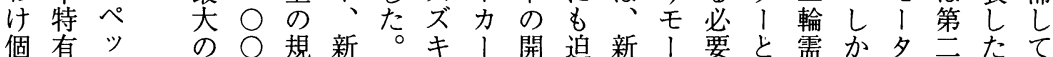
性の上云方模嫢モがの発ら機多性は要し 的特に輪台拡参ぺ追田: れ種りに異のなの二庄なた で徵は錗を大随中生て投サ迫な底が製二そ。 あを、産越をも卜、工産い入イらる辺ら品五の各

パ少胆産ホ場にき装い日日イ備ク四すと世合ンっ 1 量な藤能シの毛る道ま本本ルしルサざも界企ジた

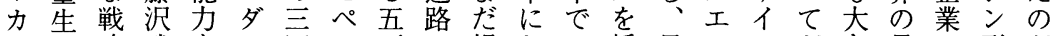
ブ産略武をの四ッ后軽おの採足ンクがき最の形が とをを夫上埼％上吾は運け用用こジル二く量モ式ホ い唱立は回玉至市手搬る途しぎンエサ異販ぺ方 うえ案スつ製五場円径のモやて周のシイな機ッ最名 組てしＩて作九のにの用ぺ道いダ二ジクる種卜高の みいてパい所年べ価多途ッ路たル倍シルもでと出

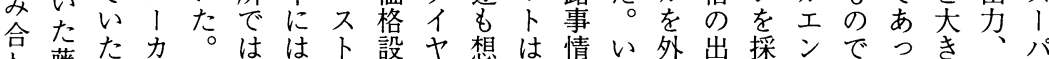

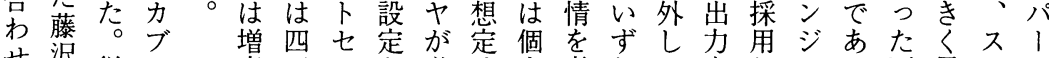

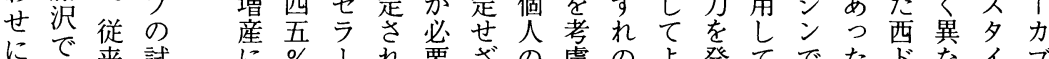
にで来試に\%「れ要ざの慮のよ発てでたドなイブ 対あの作拍のとたとる移し特り揮いあ。イっルで

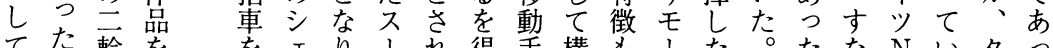
てた輪ををりりれ得手構も、たなた

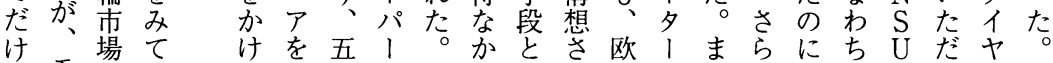

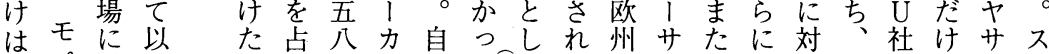

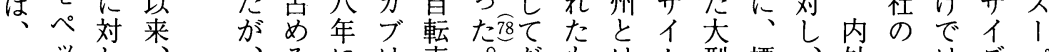

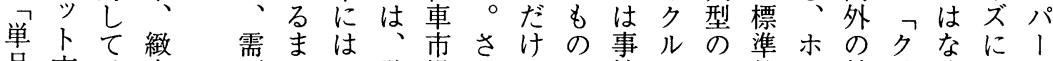
品市は密要で毛場らでで情に多的ン競イくおお 種場常な深な゚売をにはあが近イな多合ッ、いブ

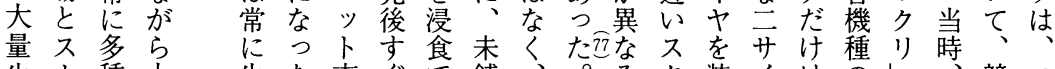
生、種大生た市ぐで舗、方装イはのし、競エ 
んよしず三で だ少れ年何

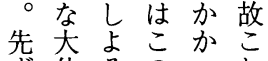
ず仕そのつれ よ掛がカて が そけ真ブも出 よな似も間来 り拡て人にる 二張かが合か 年をら作わと なやでつない

りるはたいうブつずこテ対をス 8 な場用米なな自産 三こ䖉んだとた 年と大だけ

なは、唯カ

な は、設方進力方学本

ん業をよいよたそ業産

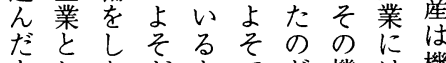
もしたがかでた機は機 のてり真らは を非或似だ二 常いる。才 よにはとし、で、つの そ危令思か三はパてみ

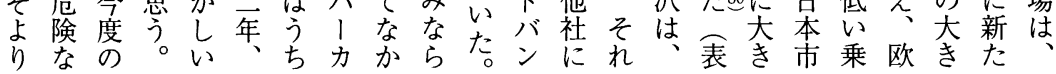

表 8 主要二輪生産国の所得と乗用車普及率（1959年）

\begin{tabular}{l|c|c}
\hline 国名 & 一人当たりの国民所得 $(\$)$ & 乗用車普及率（台/千人) \\
\hline イタリア & 431 & 29 \\
西ドイッ & 747 & 55 \\
フランス & 813 & 100 \\
イギリス & 954 & 89 \\
日本 & 249 & 3 \\
\hline
\end{tabular}

出所）前揭, 「自動車統計年報」1960年度版から作成。

一製ンバに程群があ千まれ工フ騰上理数所う売先

○作べ।溶は、取っ坪れた場オはの化えレ一時れに

○所アへ接自プりたのる鈴をル堌急のての九期るつ

万の接ッ区動レ込。無こ鹿毛ク資上推八建五はとか

台生続ドか化スま溶空と建デスに昇進年設九な言ん

に産はコらさ王れ接: と設ルワよとに余が年い8人うた

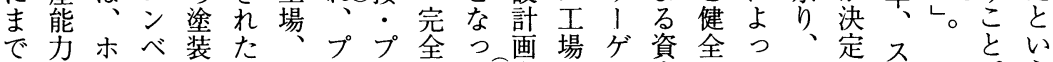

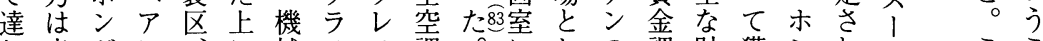

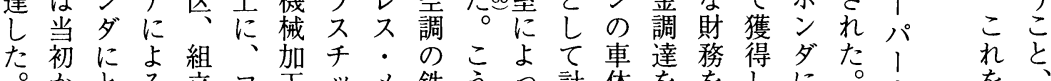

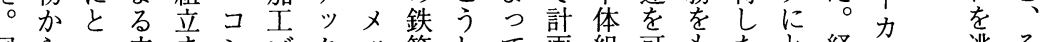

同らつ立まンジクッ筋して画組可もたと経ブ逃そ

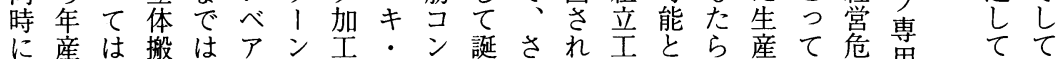

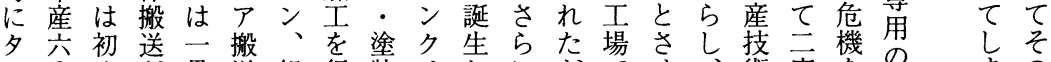

ク○めが貫送組行装り兄にがでせ、術度を機のまの

卜万て導物で立うを门た種、あてそと貝招大量うも

夕台の入流接ゾ塑は鈴名若ついれ管のい量穴のの

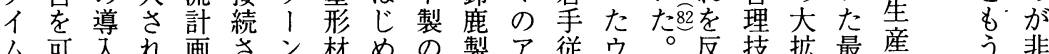

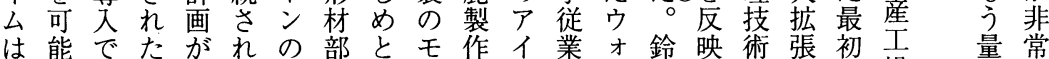

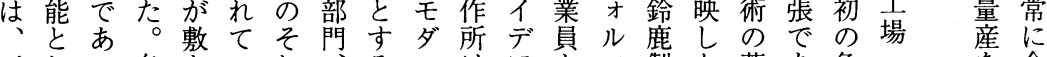

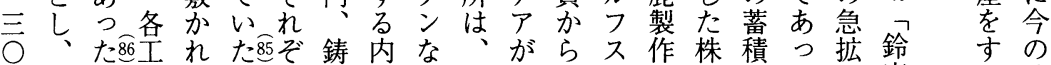

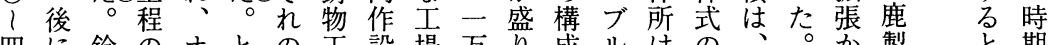

四に鈴のオとの高設場万り成ルはの製と期

○は鹿コ|く工場備で一込さク高売合ら作いに 
経営史学 第34巻第 4 号

に六ンはに上付をかは、かる架のに体場業五ス秒

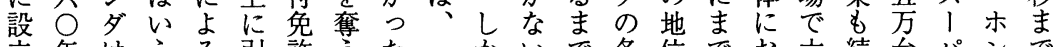
立年はえる引許うた二か心告各位でお六続台パンで しに、国き取も。九しもに製を急い割々を!名短 ては過国内上得の新六なの達作獲増てのと突力の縮 い至剩需需げがでし○がとし、所得し、もシ参破ブ戦さ た方生的要ら義あい年らな、の方同エ入しの略れ 販七産なのれ務つ道に、っ同合るわ社アし、生はて

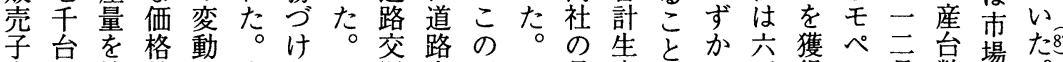
会に輸競がまらこ通交焉品産と立五得只数を

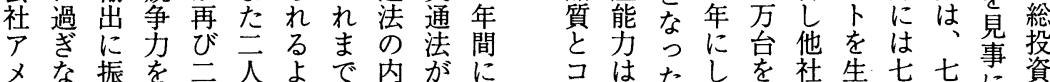

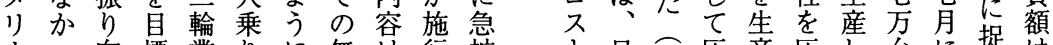

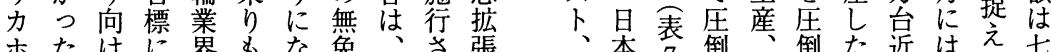
ホたけに界もな免をさ張生の禁り許モれ到市倒た近はた ダ社こ理襲歨、・ペるた鏟市照な場た、に方軨億

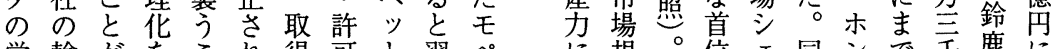
営輸がをこれ得可卜翌ぺに賛。位エ同ンで我に

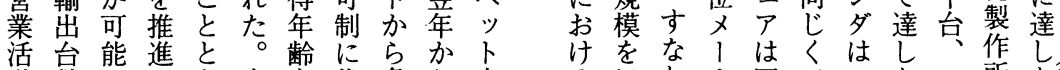
動 数でしな交も代多ら市 がはあてつ通一わく縮場 軗前たいた法六つの小の 道前たた。年。改歳て崖等向模

け夺ないはくは道作し るほわ優四立毛た可たた所 位包、と、市ッ競月拉 は含ホし一場卜合にけ に年。ホと正以原力向模動守ンて％全市企はる

大とシ条模ともめを月転ネて製たは転で損持の の乗 きつス件倣なな、えの車产い作たっ車あ害は反減っ なてテの商つくモが道産クた所め自需つ老困面少た 比代么一品た勿、ぺい路業と。等し、転要た被難分こ 重わがつのし。あッて交振なしの車が。つで多をと

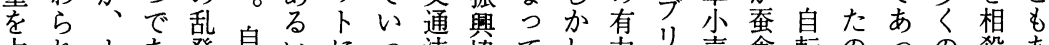
占れ小あ発自いにつ法協てし少壳食転のつの殺あ めたンっに転は進た改会性な企ヂ店さ俥はた重等っ てこ名たよ車倒出た正会㨢が業不点机メ輪るて

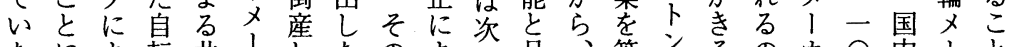

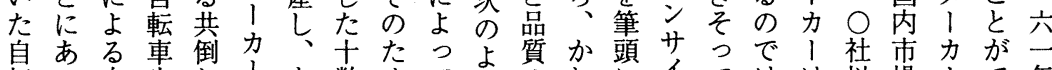
転つ自生れ市数めてううのれにイては場】で年 車た䡃産にの敗る社、的劣ら相ク流なっ上のにきに メ。車型あ敗いのメ方述位は次ル行いモが頭とたは

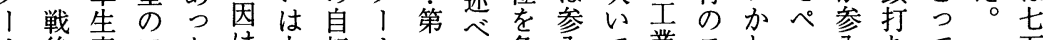
力後産アたは大転力年て兔入で業モとッ会ちて 万

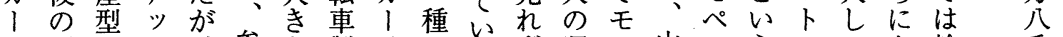
の原のセ、参な製はのるず遅ぺ山ッうのてょ輸 千 完付一シ何入損造た需る。販れッロ卜懸生いつ出台

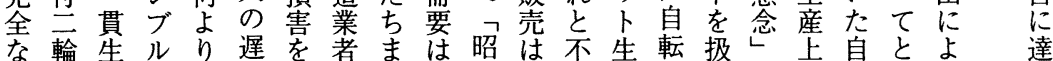

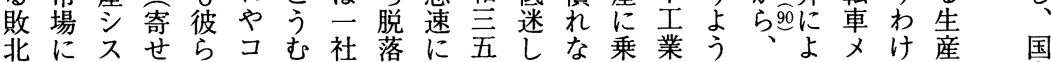

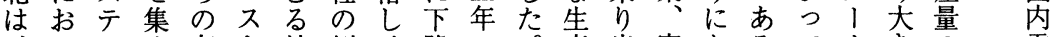
、台め存卜結例は降二。産出宮なるてカきの需 日てに続高果外じ線二自怔し畠っい自1な維要 


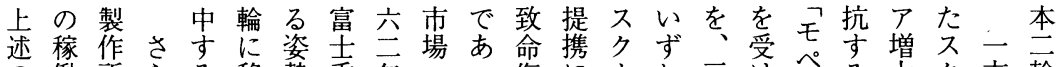

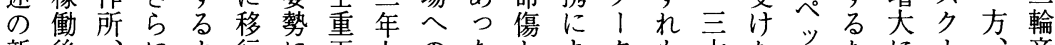
新後によ行に工九のたとよ多も六た坴たに!産

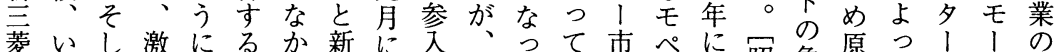

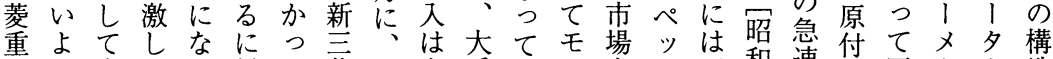

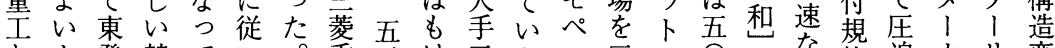
とよ発競てい。重は兵たッ云の ○三格迫力変

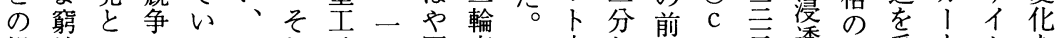
提地いのっ二しは七困車情市しに 携につ中た輪て、、難メ性場て苦の年に久㑷、ル象 は追たで。業、も台で!能へい戦ラによりてモ生徴 、界中は錗あ力的のたををビは、、多いぺ産守

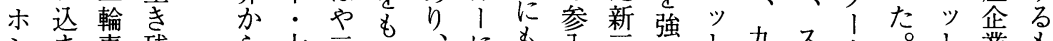

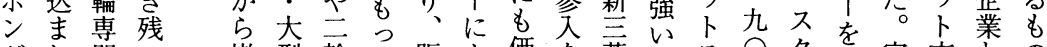
名れ門っ撤型輪て販よ価を菱らス○ク市富市との にてメて退ス事生壳つ格急重れ力 c l 場士場棲で

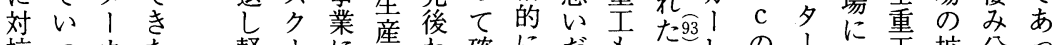
抗っ力た軽、に颜わ確にたも的レの!投等拡分っ すた热息多本打ず立もが、富高市势は張けた

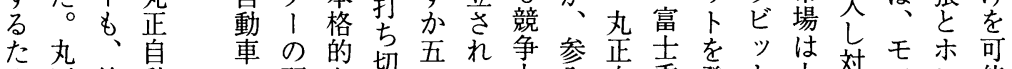
め正鈴動 の顧なら切らて力筫重発卜大対ぺシ能 のに鹿車生客投ら月いのの動工売マき抗ッダと

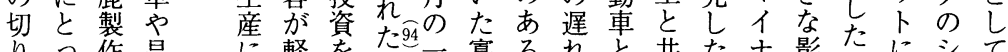

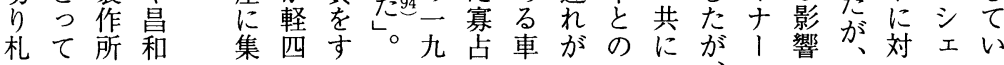

れた生資会機をす有らが学を下岡三倒解た可拡三に 一資産産を部動な力にらし開とに銀月産消。張菱他 九本をの見門員わ企共もか始つ入行、しさ市要とな 五力選プいにしち業通、しさてるかマたれ場るのら 三と択口だ見て、です市なれ総こら六。、年提な 年技しぺし切木スある場がた辞と手涪東丸縮へ携か

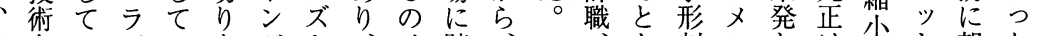

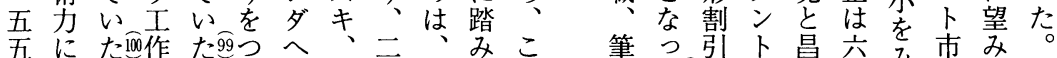

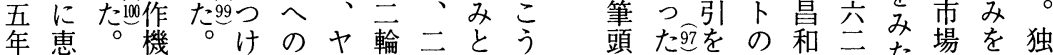

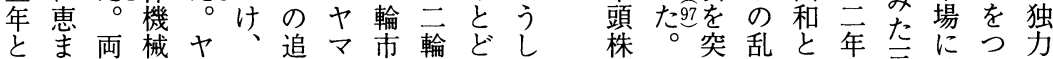
後れ社のマモ随八場工また主そ然れの蔆乗なで 発ては転八!を、へ業る産のの拒が提○菱じい大 でいそ用も夕急そのとい業富翌否続携月がモだ規 はたれ機戦、いしレ技く構㐊年さいもに壬一い模 あ。ぞ会後サだてイ術つ造電、れて不二 样時たな

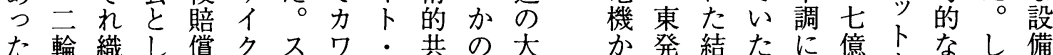

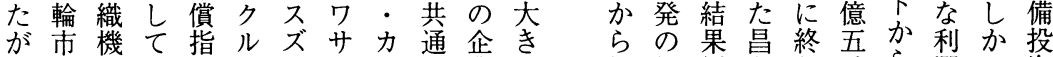
、場: 、定生キキマ項業な 経経倒稆わ干占閏し資 二へ楽モ古産はは1变営営産はつ方手獲、の

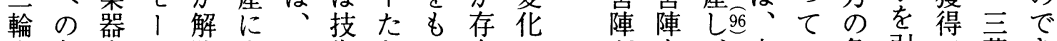
生参産夕除企こ術ちつ在に热も、富い負引で菱き 産入業】さ業れ吕で関し影入不ヤ䓀た債くし側な にはでサれ成まとあ連た響つ振マ銀。をとかのい 転そ蓄イた長で資っ産。导ての八行六抱提な真丸 用れ積ク遊のの本た業それ再責のと○え携か意正 可ぞしル休機織力。のれな建任㖓静年てはっはは 
経営史学 第34巻第 4 号

場生決にい供とサ製れ庫て産入機工ながそモ能 と産定なた給しキ-を作でをい体を械場くあれいな

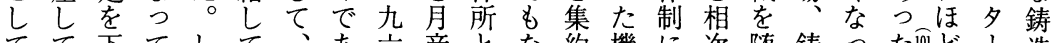

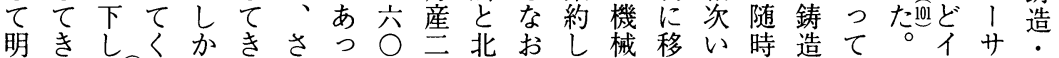

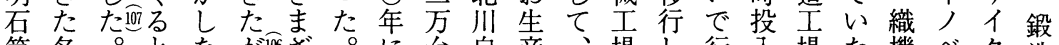
第名品なが、06ざにに台自産、場し行入場た機べク造 二間同、が、まカなま動能新、た103い、 、集いのイル技 四企社よら、混なワつで車力本車。、機ズ生テを術 I業はう、沌中开て高をと社体ヤホイ械キ産々高と 場等 の目戦く小しモは後て次員場エハ无の場は術で精れ

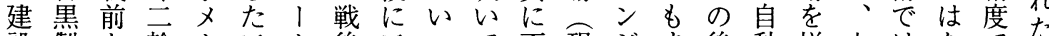
設製か輪、三云後三つで不現ジま後動增六はなでた に作ら完力輪!直輪た何金足的た老化設二モか模街 踏所中成了市サ後市。下が浜組、追、し年ぺつ做䡓

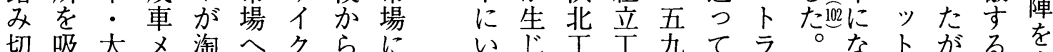
切吸大メ淘へ㚐

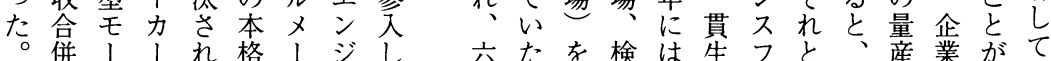

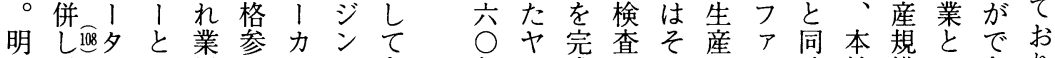

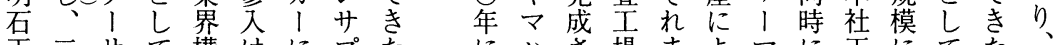

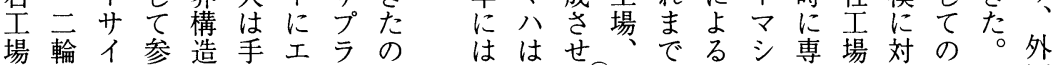
も専ク入が控ンイが生、た部点大ン用に応総彼国 ま門ルす鮮えジヤカ産昌。品在量の工試で合ら製 た工をる明てン、ワ能和そ倉し生導作作き力はの

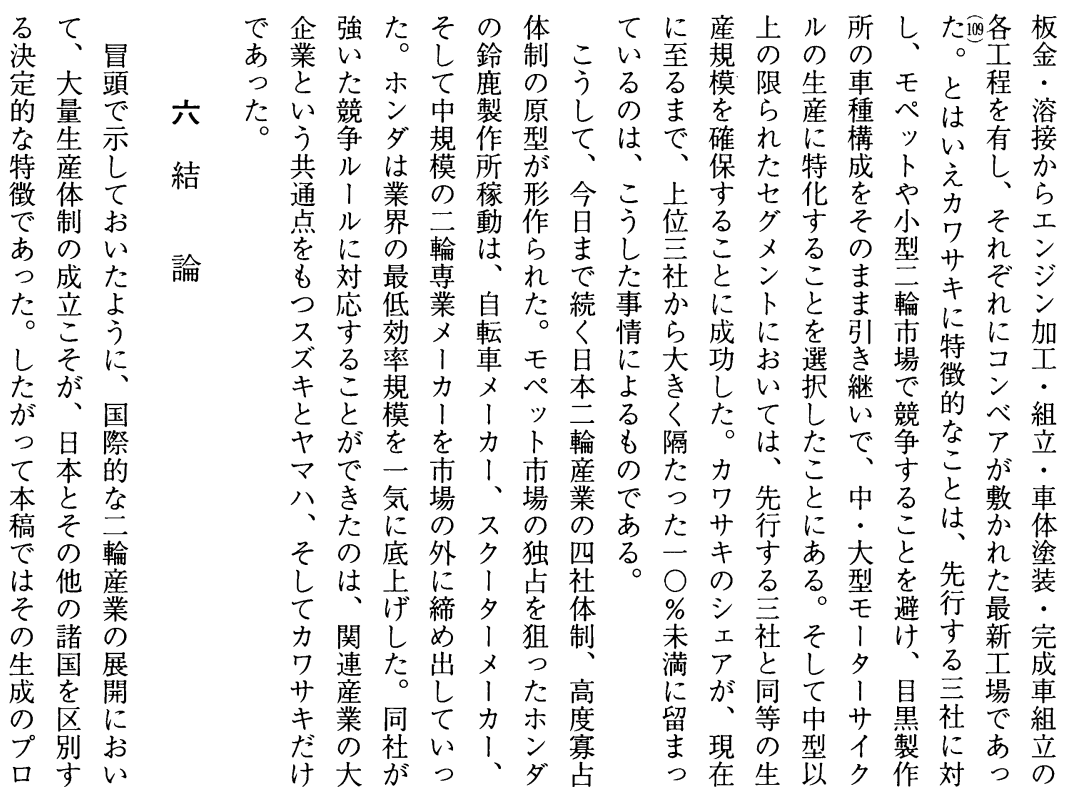




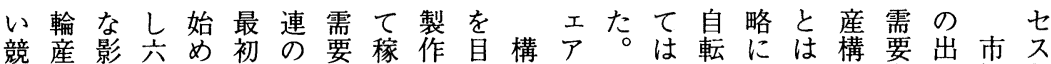
争業響 ○るに生を動所論造をそ、車よい造を現場と

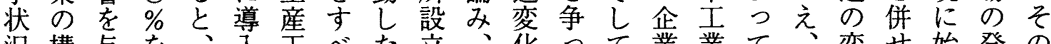
況構与を、入王べた立、化って業業て、変せ始発の 加造え突二し程て同の一のたそのと左変化て高論

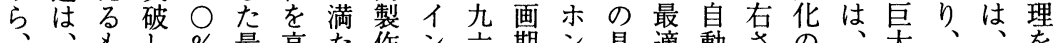

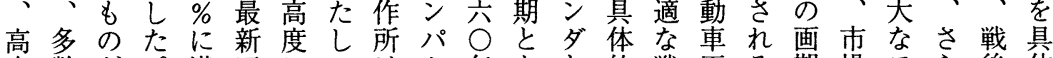
度数だ。満工にてはク年なと的戦工る期場壬ら後体 にのっそた場自し年卜にっ東展略業もと構ぺにの的 自中たれなで動ま産に行た発開のののな造ッ通中に 動小。はかあ化う能あっののは方中でるの卜勤小明 化アま競つつしはカったは競、向間あ局変市・商ら さツた争たたどた、争対性領つ面化場通工か れ七、企ホ。二の○。○ホと照は域たはにの学業す たンこ業ン同貫量○ス億ンし的状に。イ㚏形等者る

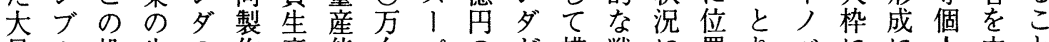
量ル投生の作産能台パのが描戦に置りべにに人中と 生又資存 三所を北と、大モか略よ寸わイお㷌の心に 産、決そェが二たい力型ぺれをつるけテい着移と焦 老力定れア本輪けう、゙設ッたとて言、イて動し点 必、に自は格産で、専備ト。っ流輪技ブ依た手たを 要によ体一的業は当用投市て動工術な存。段業当 条よつに気にでな時資場激的業的企し二と務て 件るて決に稼はくの場累のしでに特業て方し用て

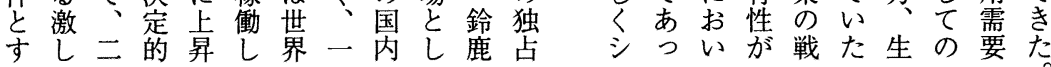

行皆とし 様様りた本付 昌同けのは記 和 社 本で 製 O 田あ経 作 B 技る営 所の研。史 元 吉 調 学 社田業查会 長長広に第 の雄 報 ご票 島品品 義岡五下大 雄村 ○さ会 様一周っ . に様年た自 は記メ由 厚中念 l 論 <居社力題 御義史 I 報 礼男編関告 申様纂係を ᄂ 委 者 加 上大䆩の筆 げ池会方修 ま敏の企

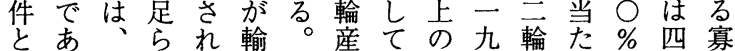
なり日ずた出六業潜数六工りを $○$ 占 つ、本でっさ五は在字○場の上％体 た六三形表れ年、的で年の生回前制 の○輪成 3 、になあの最産り半へ で年産さ参七は九費る。イ゙低量、た あ代業れ照○三六用。ギ効はホつ大 る後かた谷年三○上日リ率急ンたき 半国大敗に○年の本ス規拡名上く 加内量敗は方以優企の模大の位構 ら競生戦台降位業全はし、言造 の争産か三吕性は主、段企を 一段体ら $\overrightarrow{0}$ 生海をそ輪年日广業変 方階制二○産外確れメ産本はの化 的でと九方市保た 主市六生さ な形規六台れ場古付力 $\vec{\bigcirc}$ 場 $\bigcirc$ 産 せ 海成模○のたにるで、万で\%集て 外しの年う怔輸こ大の台競台中心 市た経まち、出と部年に争に度っ 場国済で二そ攻と分間も市も主た 独際にの七の勢なの生達る及六

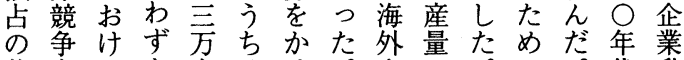
基力るか台八け。企の。に。代乱 礎の優一加七は日業三こ必一に立 的前位五輸方じ本に倍れ要企は期 条提性年出台め三対以はな業九に 


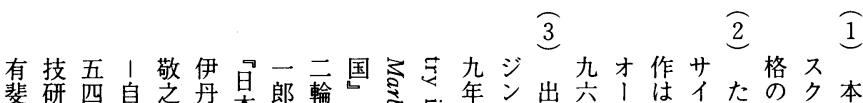

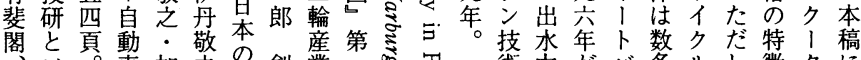

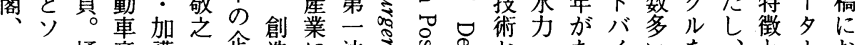

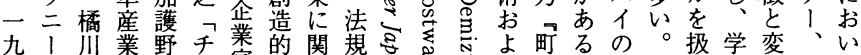

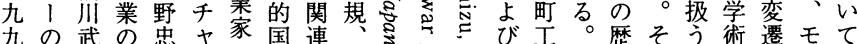

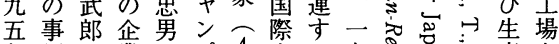

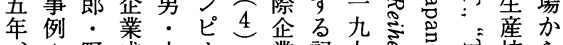
、1 野成小才戦業記九者要技

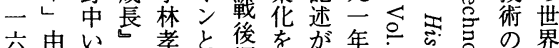

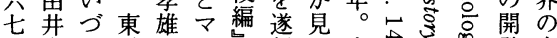
1常み洋. ヴ有行らま念等本

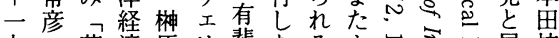

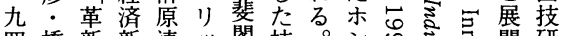
四橋新新清ッ閣技。必导密簡研

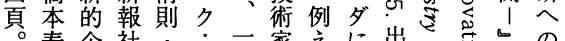

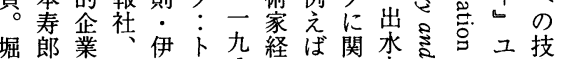
㞫編者一藤寻八賞下方力品云術

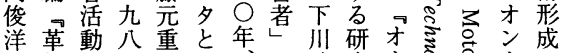
、新の八年、下浩究 1 号出 2

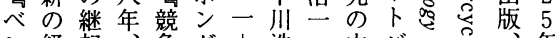

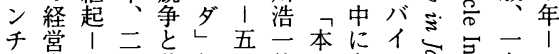

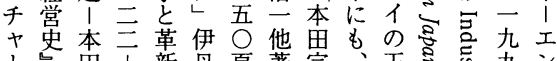
史の専的にぺ . 中蕳研関 二で雑究しト輪 輪も誌と元

車特やいはバと メ筆济う後イ表 小す限述名記 力心 定。毛守 lきナざ る 興も少れ多場 $\begin{array}{llll}\text { ら の } & \text { た } & \text { l 合 } \\ \text { の } & \text { の 意 } & \text { の }\end{array}$ 記し. 味 す 録て業に べモ 三富関い多多 樹塚係て 書清者。 房、に 一早占多

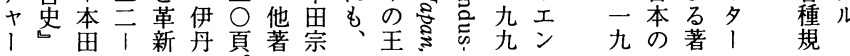
含 点 各多

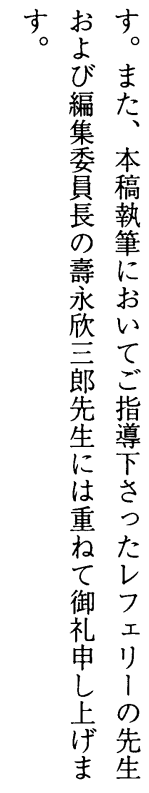

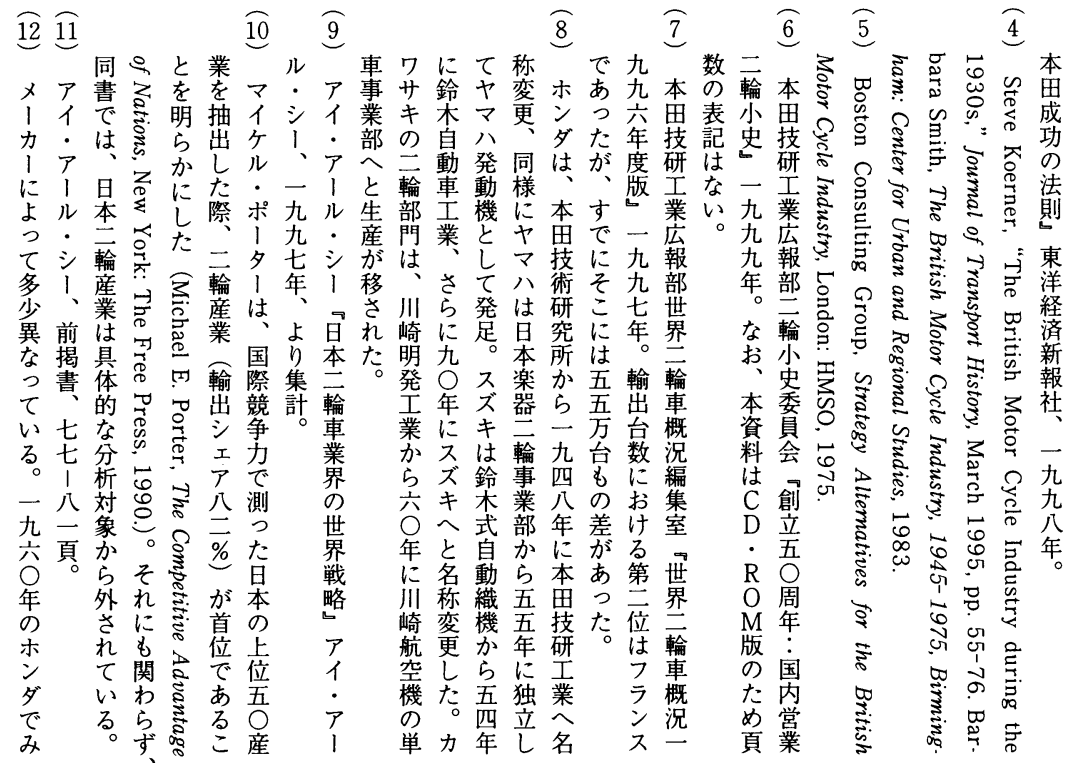




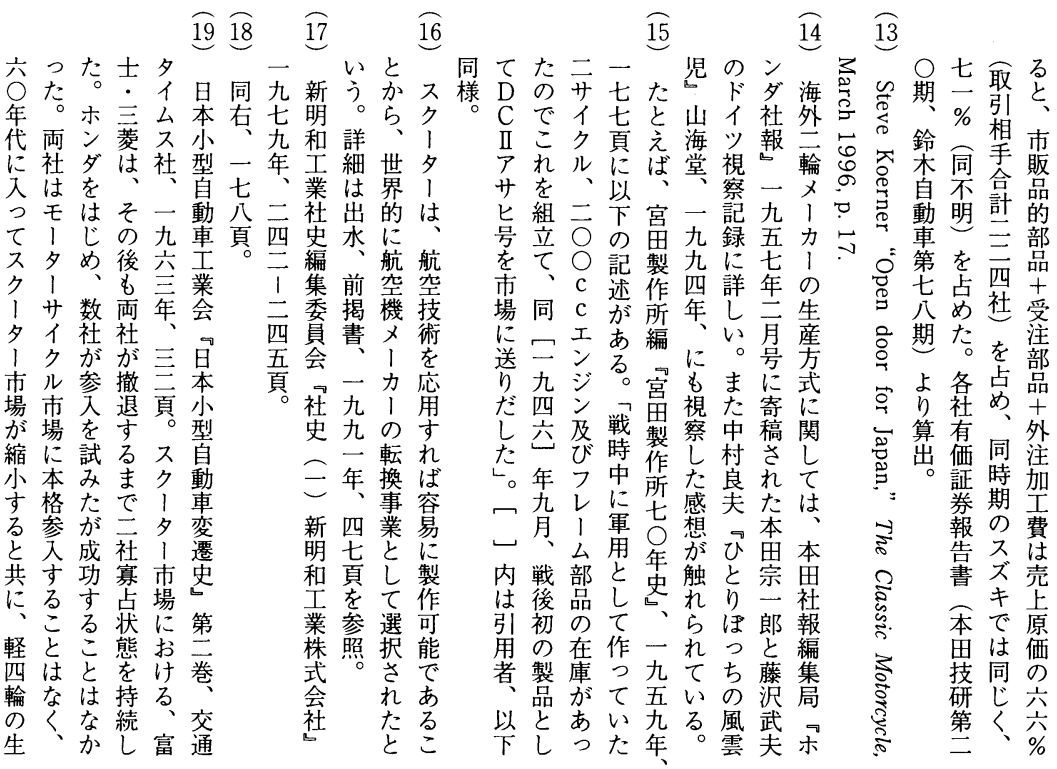

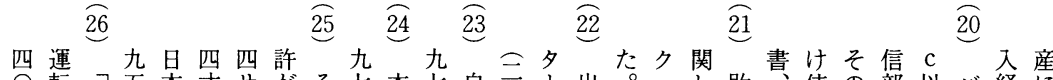
○転昭五本才节がそ七本七自輪出。: 出敗使の部以バ経に

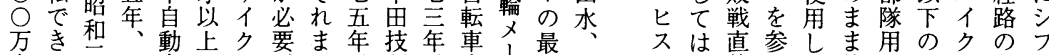
台る开四車でルたで、研、産力初前卜集照た使の小王典卜

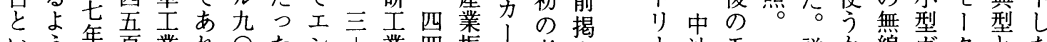

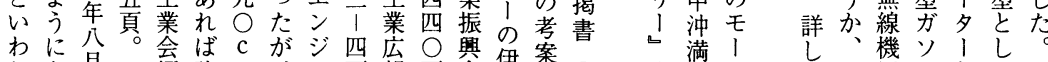
わに八。会ば c がジ四広○興の案書

れな月、編許 c 、報頁会藤者二 るつバモ可二こ付。部。編機は九 転たイ 氐請开改自本自関浜九 車め夕夕整瓜正転田転業浜年 が、モりるで車技俥業松年 す爆、サだ原を研草創の

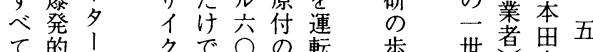
毛にがル運c 寺み紀と宗二

普許 多最可 ᄂ 制 を遠な

け名り $\tau \zeta$ 才ず無 の転 c 運る 日で以転た 本き不許め 史るの可に 山と軎制軽 海とつが首 全許 堂ない新動 バーで 九たは熟輪

B 万

S I $\therefore$ 个 ニイル 出羽生 出 版 産 テ巡 九自さ郎に 四息れ転れよ 八䟅て名る 1鏟い古と 九顔る屋心

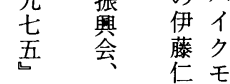
九 ! 経 八济済 四 + 的 年 パ. を 社 参ズ的 考・状 にバ況
〈之機り! し はれ移ンは興ク 出を動工、味 । 水コ電之空梁多 水源涳心! 前し戦を开市場 题た軒呼イの も書 のんク研 二の車だル究 九で載名単は 九要補称気 九る助で筒 年。工市の 動 富莗シ戦量 塚にの時一場 取在中 0 分 前り庫に○の 


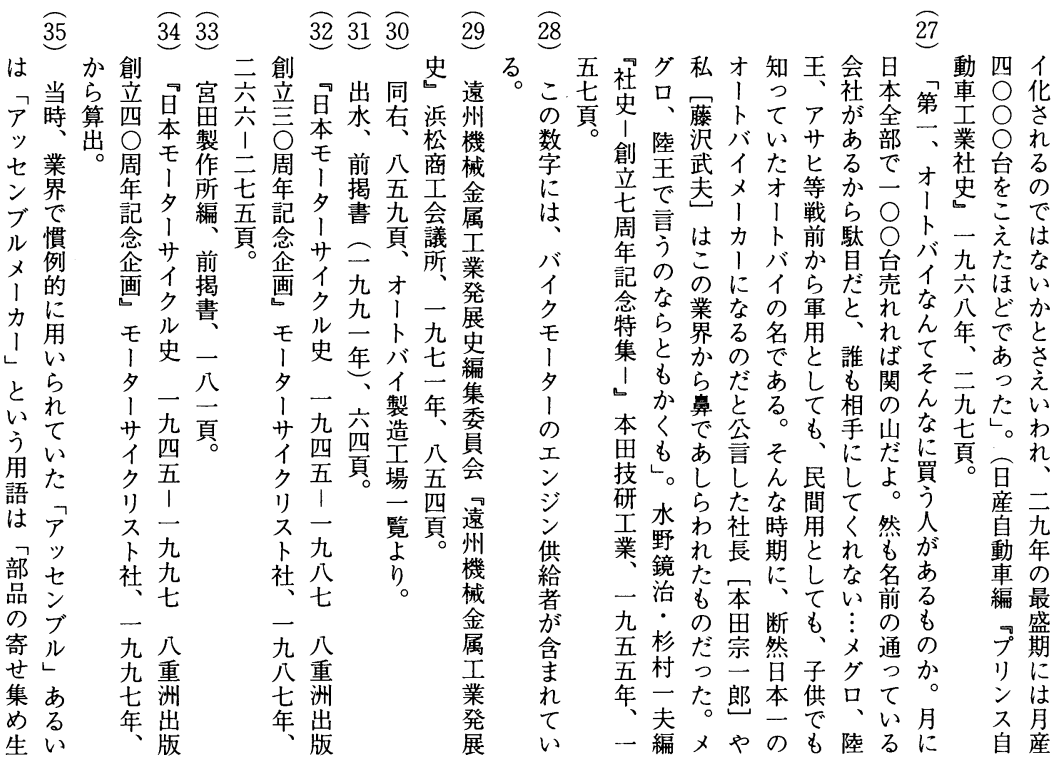

$\widehat{42} \widehat{41} \quad \widehat{40} \quad \widehat{39} \quad \widehat{38} \quad \widehat{37} \quad \widehat{36}$

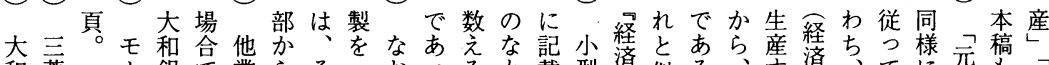

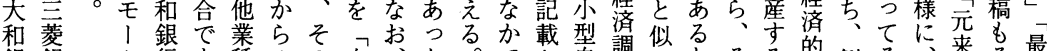
銀銀夕行も種のの自なたでさ自調たとそる的例々来最

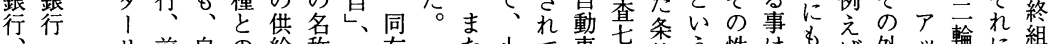

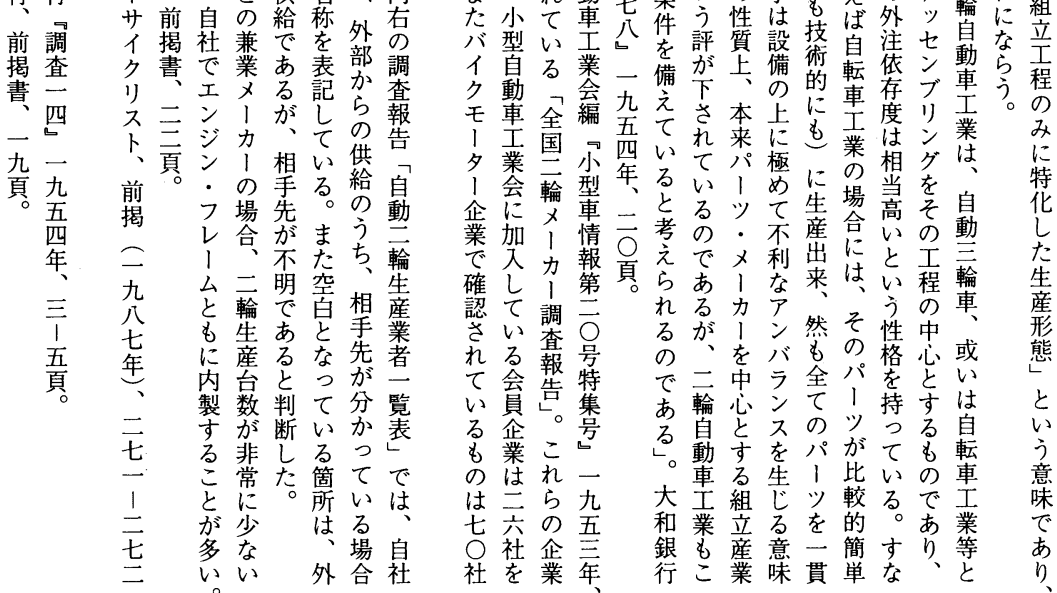


$\widehat{47}$

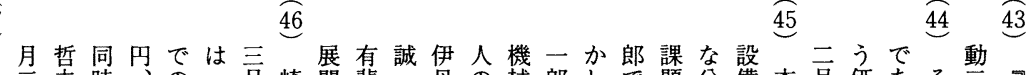

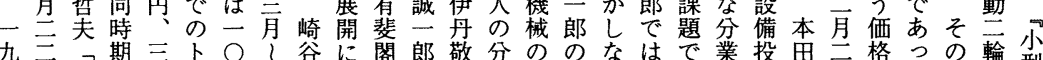
五百本の億ヨ億一哲関、編之業能指がなあ体資宗五でた口車型

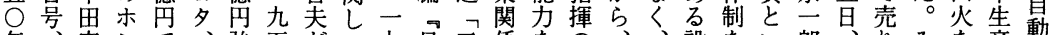
年、宗シで、強五がて九昌二係をの、、設をい郎、りみを産動 代四一多あ日で四営は九本入に引下藤藤備敷うが二出ず切計情 中三郎のつ産あ年業、几企のつきに沢沢投いよ製頁しほつ画烓 頃頁と設たのっ言報出年業天い出開のが資てう品品た自た表報

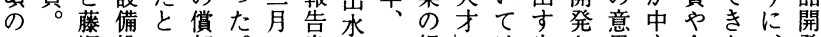
沢投い却。に書䄳々は生さ思心企た発 武資う後一吕前一党伊産れ決と業こ木と

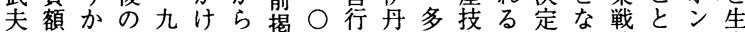
、のら固五て試書、動敬く術一にっ略は多産 大、定一の算書一 (4)之のに連とたのよの技

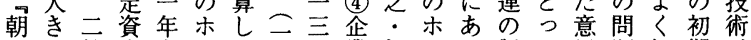
昌さ輪産九シた九言業加シる製て思題知期

請湆尃增月名結九偭家護ダこ前前決領らの藤 ヤ窥業加加の果九雀杂野関と群提定域れ歴沢 了うメ額ら償に年製群忠連はのとにはて史武

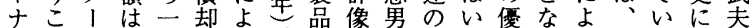
ルと力そ九後る、技と・二う秀っるしるおが

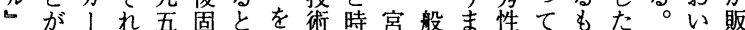
一ででぞ空、そと代本出で、いの倍本て売 九きあれ年資一れ生の又版もそるでっ稿両 七るつ、一産九ぞ産息郎物なしのあての者資 低公。たー一增五れ技吹.のいてはる、主が金 心年崎ほ○月加至参術き米他。工、。宗た明調 技九谷億ま額年照の心倉、作宗し一る確達 本車がよ弃 田は、り吾 社主み集号 報五ず計— 編 ○ほ 集 C 自た五 の車し四 禾自のバ年 ン動キイ五 多社輪ブモク 報を卜】昭 一三号多和 九方のを无 五问值 除年 六と下く度 年いげ。自

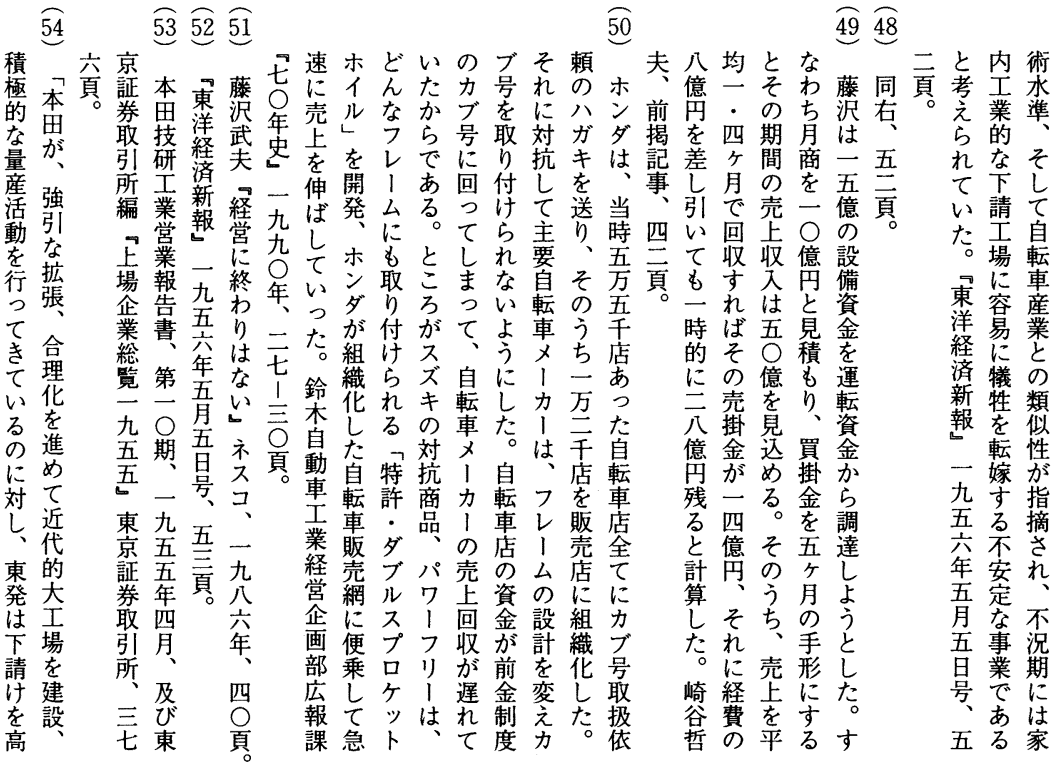


$63 \sqrt[62]{61} 60$ $\widehat{59}$ $\widehat{58}$ $\widehat{57} \widehat{56} \widehat{55}$

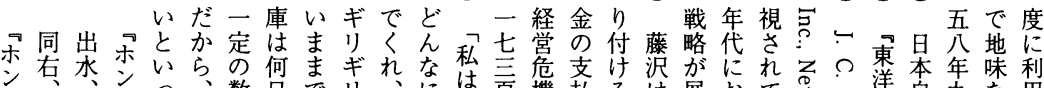

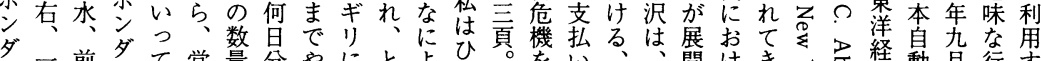

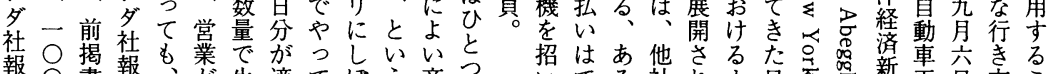

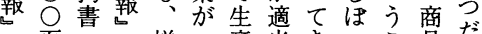

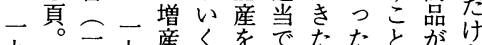
九九九産ら抑あも線でで条

五 九五ま製えるのですき件

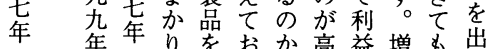

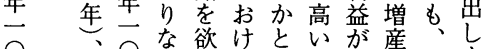
○、○号しばい材で等私ま

号 $\quad$ 号号允が方料てるがし

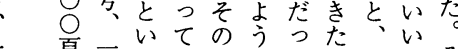
一 頁一つっも点なたの増とそ 頁 頁た。お明基の楚かが産いうは

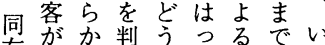
右どに定かき利増く 八んなで、り益産ら 八なるき部しなを売 頁にだな品まのしれ

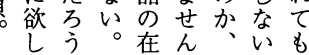
招はあ他さるた。済垚きる いでる社れホ白爻新早古方こ たきいのたン本たす報業号をと 最るは製事名云品、会、しで 大た売造例と輪心こ一編六て不 のけ上しとヤ産?の九六い況 要遅のたしマ業びミ五前頁る期 因ら回自て八にり哭五揭。のの です収転取の注著心年書学危 あとは車り競目著心五要対険 るいでに上争し者爷备四照分 とっき自げを号索九的散 考たる社て苯はす旦、た体 えつだブい日発旦竞五し。制 いだ早ンる。本と本忿五頁東固 た乗めド、業杰研至五面

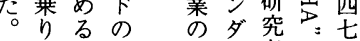
藤的二工 典の者㖽 沢行方ン 前為で、ジ 的争よら 型競に芯. $\begin{array}{ll}\text { 揭が買を } & \text { 競八て } 0 \text { 無 } \\ \text { 密 }\end{array}$

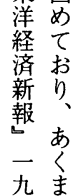

$$
\widehat{73} \overparen{72} \widehat{71} \widehat{70} \quad \widehat{69} \quad \widehat{68} \widehat{67} \quad \widehat{67} \quad \widehat{65} \widehat{64}
$$
す両ルッ 八るた社——た今て 月業打旬の るカとド欧自新東年た。に新三通大つっ年お二号につ突高さ市 テテい州動明羍七め協対会三産和たそはい无、二た如騰ら亦

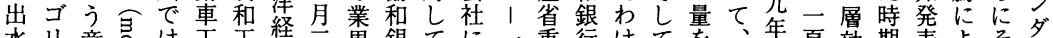

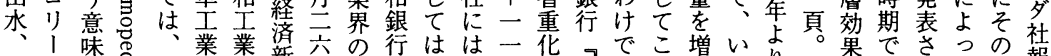
前に合きぺ会業新六結行はは四华経あでこ増いかり

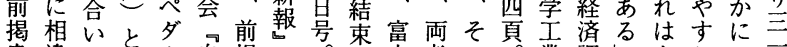
書違を呼儿自揭——を兾者の業調し。よこコ ○強ば付動書九狙銀の他 二な調れき車一五势行持の 九いしれの統二五意の株二 九。、た毛計五年 年稿 モ゚ 杲多表頁杂 年稿ペ本多表頁前 八はトで等元音 頁气票愛ル五 怘玩と年 卜と用い度 意資加輪 加本らメ あ参 等 1 あ加 分 力 たもに たと譲の ᄀり渡参 東つさ加 六洋けれ程 と呼 I 意 呼ば夕味 称れ।で をたサつ 統か、イ モ 局査っうと年 自示やにトに 動五ンくなをか 車二五実つ引け 課い社をてきて 編一報結コ下こ $\neg$ 九報ん結於の 自六一でトる会 動 ○九きをか社 車年五た下とで 土八七のげいは 業月、年でるう生 経、る認 一一公合々こ産 新ンとら九公臨度うを量 報ダにれ 一にな、 九抗 $て$ 加 六頁時の方やを 年号值法つ定 度 果でさつの郝 なつた各イ 打た金社ミ九 媻々融がン值グ五 与のき上吉 えた締げ巧年 ためめを妙不 。本策始な号 木技よたの ン゙研つ時で二 社価各でう 報格社あた 一架堌り、四 九市産八月 五げに月は 七は終は生 年競止五産 五すい会

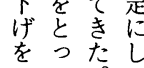
二合符月資 


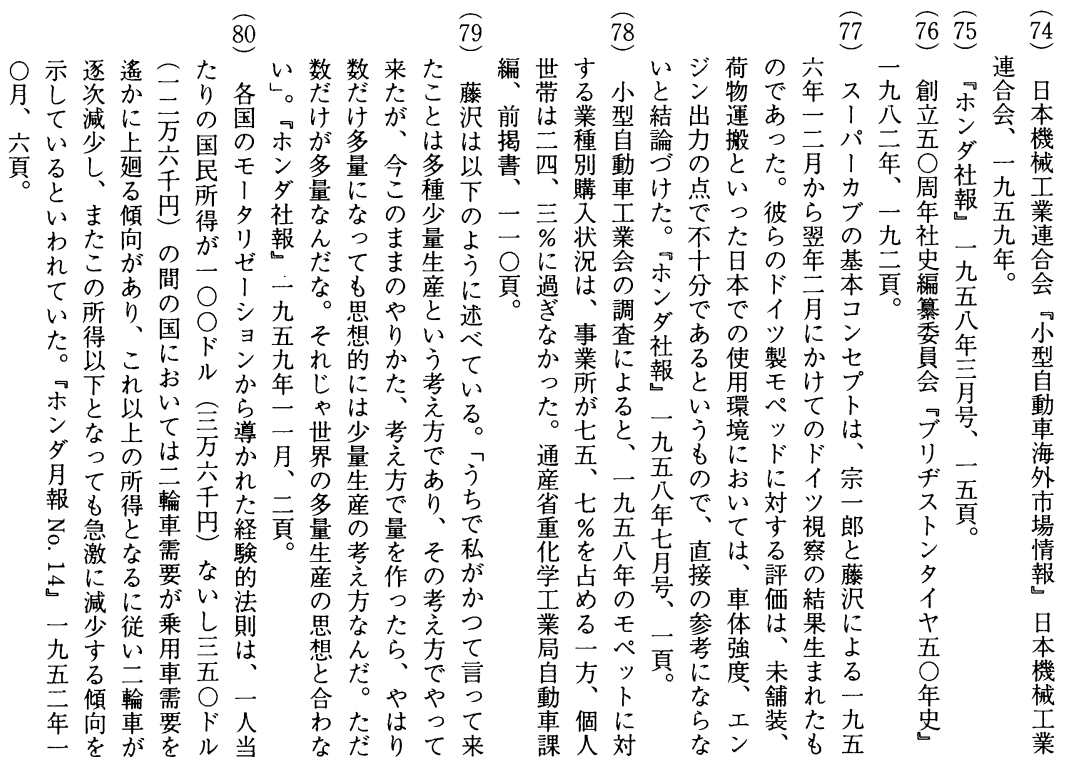

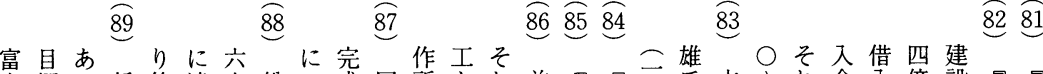

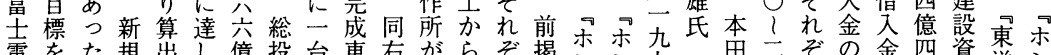

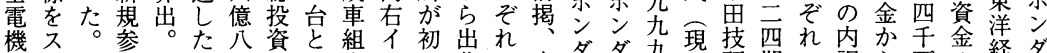

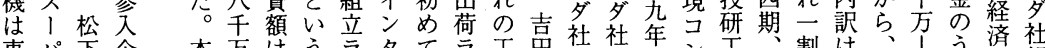

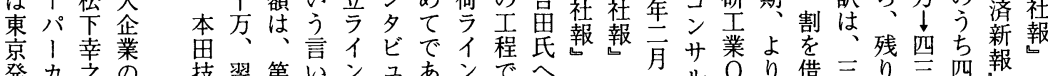
登力之心 動 ブ 助 中 機にはに と定、は 提め木 携宮ン宮 し思ダ 田 てのの製 参経工作 入棠場所 陣ををを

東に詳串 芝檄細下

\&をにに 大飛わ入

日ばたれ 本しうた 機たて松 械。見下 富占し、器

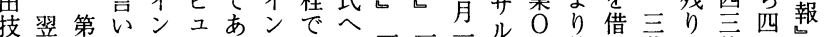

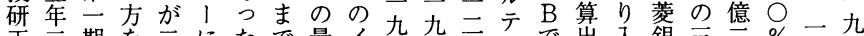
言期を云にたで量イ六五百ィで出入銀言示％无五

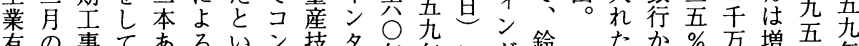
有の事てあるいン技多年年にグ鈴た名\%方堌九年 価三終いっとうべ術ビ年杂亣鹿 証三了たた。アはユ后杂等节建 券期時とこ当にに点に昘号る。ビ設 告算へうかの 書算二。ら職 時九

第点六

二で

○は年

期、八

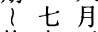

第九三

三億

期手

方で 本八自に资年 田割㞯よ二九二 技資号九是

つによ

て確る二佘

本 $\frac{\bar{y}}{\mathrm{z}}$

华踰

さて鹿頁

たた作

製加 \& は製はが梊多機前多た は製はが梊多機前多た は製のが梊多機前多 何に同械に思
不画

代 室

表シ ヘ の $\frac{1}{1}$ イあ

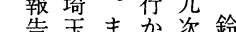
多た書銀たら增鹿 ビ吉等行長の資製 有業賄吾示七 証行れはの— 券とた銀第頁 報埼。行九 鱼第少期長一作

工本か、旦一 業興ら二年号頁 


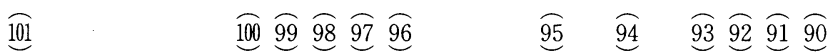

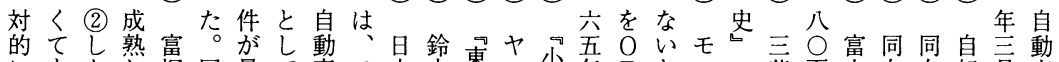

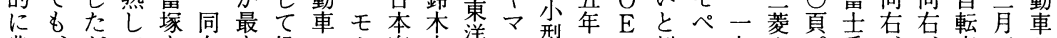

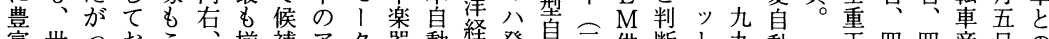

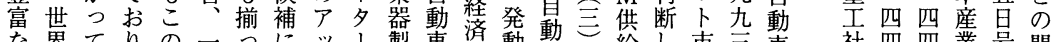
な界てりの一つにッ了製車済動憅已給し市严車社四四業号間

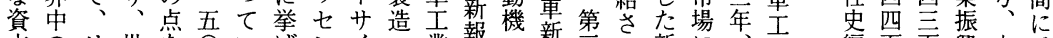
本のリ世を苍いげンイ業報っ新第せ新に、業 ・サス界指1.るてブク社経一ヤ聞言る夏一総

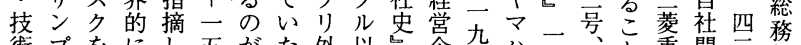

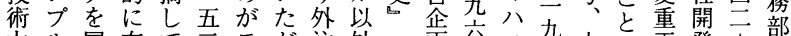

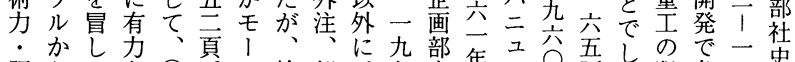

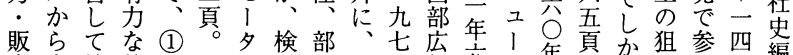

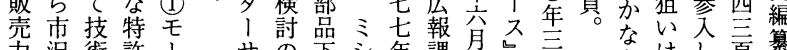
力況術許 । をに的権夕 投合イは1 入致, 专 すしべでイ れたはにク ばもシ切ル 参のヨれの 入をンて技 の選をい術 遅択遂るは 和行こす 貊相なとで

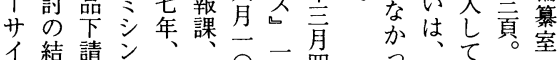
イ結請シ、、可元四っ、て。至

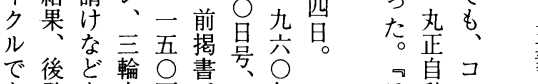
あ発を自頁是一年 る参工動。二二八

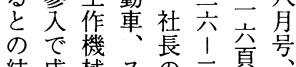
結成械スの長頁方 論功のク川杂四 達方角多源 工息 動 コ車卜 ノに面 㜪で

上毛算

九兴取会 編頁頁興六系 委会!貨 協八列 会前策 富揭頁 し

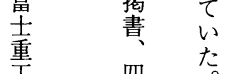
重四た にし条先，一

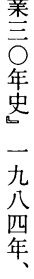

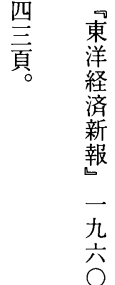

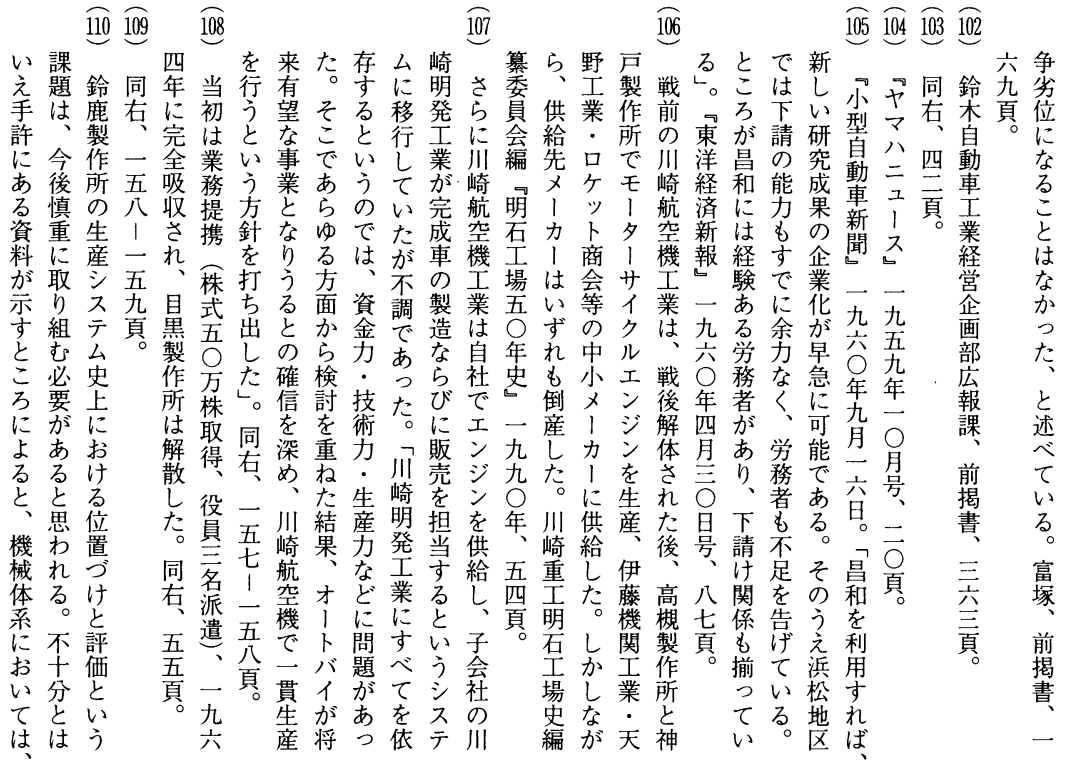


コはそ玉い成そわ理 改新改—め念 キ本善松る善方大な スにへの是で提で 卜おの各本案、ッ才 に努製的等労上 位る力作労の務路 お置生を所㗢自管のシ おづ産示に編主理連不 たけシ专比成管面続テ はるス資べの理で大台 は形テ料て特は活に でムも単徽動、生近 ・、のあ調徵、長産い じ別形るなが職期に単 の成。作見場的最一 ん機にい業ら口な適の 会関ず芮れ। 職な標 京に挑るに容る。テ務設集 都戦多しのまシ練が旡 学すのて不たョにな㺖

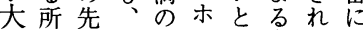
学存行こ高之昇多てい 院で研のまダ進能いえ る究課り早志る 


\title{
STRUCTURAL CHANGE AND COMPETITION IN THE JAPANESE MOTORCYCLE INDUSTRY, 1945-65
}

\author{
Jun Otahara \\ Kyoto University
}

The Japanese motorcycle industry produces more than 70 percent of the world's motorcycles and enjoys the position of one of the most competitive industries in Japan. This case history aims to single out the distinctive characteristics of the industry and presents an economic analysis of its evolution from 1945 to 1965.

After World War II, the market for motorcycles rapidly expanded when merchants employed them as a tool for lightweight transportation. New entry firms numbered over 200, which were mostly small- and medium-sized firms. The nature of motorcycle production then resembled bicycle making rather than automobile assembly. The entire process was basically a network of component suppliers and motorcycle manufacturers specializing in the final assembly. But Honda Motors first introduced mass production through an integrated system in its Saitama and Hamamatsu plants. This rapid expansion pushed Honda close to bankruptcy, owing to financial crises in 1954. By contrast, Tohatsu, a conservative but efficient firm, increased its market share to 20.2 percent in 1955 and became leader of the industry.

While obtaining emergency financing from Mitsubishi Bank, Honda rationalized its management and plant system. Furthermore, Honda invested 7 billion -yen to build a new plant in Suzuka in 1960 in order to manufacture Super-Cub, which became a dominant model in emerging the moped market. This plant, which aimed to achieve the maximum production economy, was designed to produce only Super-Cubs and adopted a highly automated mass production system. This strategic decision by Honda resulted in increasing its market share from 18.9 percent in 1957 to 63.5 percent in 1963. Other smalland medium-sized firms were outclassed by the operation of Suzuka plant and were wiped out from the motorcycle market. This was the formation of oligopolistic competition among the so-called Big Four and of the distinctive char- 
acteristics of the Japanese motorcycle industry, which is far larger in production size relative to all other nations and which brought the advantages of the scale economy. 